\title{
Mineral Resources of the Turtle Mountains Wilderness Study Area, San Bernardino County, California
}

\section{U.S. GEOLOGICAL SURVEY BULLETIN 1713-B}

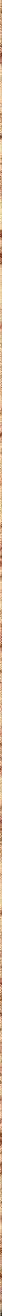


. 
Chapter B

\section{Mineral Resources of the \\ Turtle Mountains Wilderness Study Area, San Bernardino County, California}

By KEITH A. HOWARD, JANE E. NIELSON, ROBERT W. SIMPSON, RICHARD W. HAZLETT HENRY V. ALMINAS, and JOHN K. NAKATA U.S. Geological Survey

JOHN R. MCDONNELL, JR.

U.S. Bureau of Mines

MINERAL RESOURCES OF WILDERNESS STUDY AREAS:

EASTERN CALIFORNIA DESERT CONSERVATION AREA, CALIFORNIA 


\section{DEPARTMENT OF THE INTERIOR DONALD PAUL HODEL, Secretary \\ U.S. GEOLOGICAL SURVEY \\ Dallas L. Peck, Director}

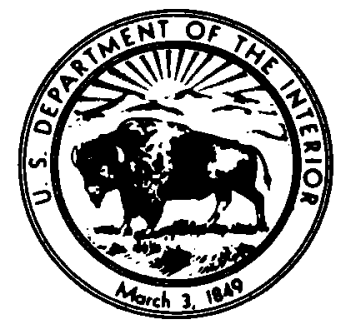

For sale by the

Books and Open-File Reports Section

U.S. Geological Survey

Federal Center, Box 25425

Denver, CO 80225

Library of Congress Cataloging-in-Publication Data

Mineral resources of the Turtle Mountains Wilderness

Study Area, San Bernardino County, California.

U.S. Geological Survey Bulletin 1713-B

Bibliography

Supt. of Docs. No.: 1 19.3:1713-B

1. Mines and mineral resources-California-Turtle

Mountains Wilderness. 2. Turtle Mountains Wilderness

(Calif.) I. Howard, Keith A. II. Series

QE75.B9 No. 1713-B $\quad 557.3 \mathrm{~s} \quad 87-600322$

[TN24.C2]

|553'.09794'95| 


\section{STUDIES RELATED TO WILDERNESS}

\section{Bureau of Land Management Wilderness Study Area}

The Federal Land Policy and Management Act (Public Law 94-579, October 21, 1976) requires the U.S. Geological Survey and U.S. Bureau of Mines to conduct mineral surveys on certain areas to determine the mineral values, if any, that may be present. Results must be made available to the public and be submitted to the President and the Congress. This report summarizes the results of a mineral survey of the Turtle Mountains Wilderness Study Area (CDCA-307), California Desert Conservation Area, San Bernardino County, California. 



\section{CONTENTS}

\section{Summary B1}

Abstract 1

Character and setting 1

Mineral resources and mineral resource potential $\mathbf{3}$

Introduction $\mathbf{3}$

Methods of investigation 3

Acknowledgments 5

Geologic setting 6

Appraisal of identified resources 6

Mining history 6

Identified resources and mineralized areas 6

Metallic minerals 7

Horn Spring area 7

Martins Well area 7

Placer claims 8

Nonmetallic minerals 8

Recommendations for future work 8

Assessment of mineral resource potential 10

Geology 10

Rock units 10

Faults 11

Altered rocks 11

Geochemistry 12

Geophysics 13

Aeromagnetic data 13

Gravity data 14

Radiometric surveys 14

Mineral and energy resource potential 14

Gold, silver, and associated metals (lode) 14

Deposit description 15

Deposit age and type 15

Assessment 16

Gold and silver (placer) 17

Manganese 17

Uranium and thorium 17

Perlite 18

Pegmatite minerals 18

Omamental stone 18

Oil and gas 18

Recommendations for future work 18

References cited 19

Appendixes

Definition of levels of mineral resource potential and certainty of assessment 23

Resource/reserve classification $\mathbf{2 4}$

Geologic time chart 25

\section{PLATE}

[In pocket]

1. Mineral resource potential map of the Turtle Mountains Wilderness Study Area, San Bernardino County, California 


\section{FIGURES}

1. Map showing location of Turtle Mountains Wilderness Study Area, San Bernardino County, Califomia B2

2. Map showing mineral resource potential, general geology, and mines, prospects, and claims in Turtle Mountains Wilderness Study Area 4

3. Map of Turtle Mountains Wilderness Study Area showing areas of altered rocks and geochemically anomalous areas 9

\section{TABLES}

1. Mineral deposits and occurrences in and near the Turtle Mountains Wilderness Study Area B26

2. Summary of regional geochemical survey of the Turtle Mountains Wilderness Study Area 28 


\title{
Mineral Resources of the Turtle Mountains Wilderness Study Area, San Bernardino County, California
}

\author{
By Keith A. Howard, Jane E. Nielson, Robert W. Simpson, \\ Richard W. Hazlett, Henry V. Alminas, and John K. Nakata \\ U.S. Geological Survey
}

John R. McDonnell, Jr. U.S. Bureau of Mines

\section{SUMMARY}

\begin{abstract}
At the request of the U.S. Bureau of Land Management, approximately 105,200 acres of the Turtle Mountains Wilderness Study Area (CDCA-307) were evaluated for mineral resources (known) and resource potential (undiscovered). In this report, the area studied is referred to as "the wilderness study area" or simply "the study area"; any reference to the Turtle Mountain Wilderness Study Area refers only to that part of the wilderness study area for which a mineral survey was requested by the U.S. Bureau of Land Management.

The wilderness study area is in southeastern San Bernardino County, Calif. Gold, silver, copper, and lead have been mined within and adjacent to the study area. Copper-zinc-silver-gold mineral occurrences are found in the southern part and goldsilver mineral occurrences are found in the northern part of the study area; identified low- to moderate-grade gold-silver resources occur adjacent to the study area along the western boundary. Six areas in the south-central and northwestern parts of the study area have high resource potential, two broad areas have moderate resource potential, and part of the southwest corner has low resource potential for lode gold, silver, and associated copper, lead, zinc, molybdenum, and tungsten. Alluvium locally within one of these areas has moderate resource potential for placer gold and silver, and the entire area has low resource potential for placer gold and silver. There is low resource potential for perlite, ornamental stone (onyx marble and opal), manganese, uranium and thorium, pegmatite minerals, and oil and gas within the study area. Sand and gravel are abundant but are readily available outside the wilderness study area.
\end{abstract}

\section{Character and Setting}

The Turtle Mountains Wilderness Study Area (CDCA307) is in southeastem San Bernardino County, Calif., about $35 \mathrm{mi}$ south of Needles (fig. 1). The study area encompasses approximately 105,200 acres in and around the Turtle Mountains and the Mopah Range; both are dry desert ranges. Elevations range from 4,313 ft in the Turtle Mountains to $1,120 \mathrm{ft}$ in the flanking alluvial lowlands. A crystalline basement terrane underlies the western two thirds of the study area, and consists of gneiss, diorite, and granite, and diabase dikes of Proterozoic age (about 1,100 to 2,000 million years before present (Ma); see geologic time chart in appendixes), granodiorite and diorite plutons of Cretaceous age (70-120 $\mathrm{Ma}$ ), and quartz porphyry dikes of probable Cretaceous age. Normal faults separate this basement terrane from Miocene (about 14 to $22 \mathrm{Ma}$ ) volcanic and sedimentary rocks in the Mopah Range in the eastern part of the study area. The Miocene rocks include mafic to silicic lava flows, breccias, pyroclastic rocks, feeder plugs and dikes, and sedimentary rocks. Faults that were active during the Miocene volcanism cut both terranes. The Miocene faulting was part of a regional episode of crustal extension. Major low-angle normal faults that formed during this episode are exposed in the Whipple Mountains $5 \mathrm{mi}$ to the east and probably underlie the study area at depth.

Gold and copper mining in and near the study area, beginning as early as 1862 , has been largely in the form of small operations working on individual veins in the Proterozoic and Cretaceous rocks. Mines in the study area 


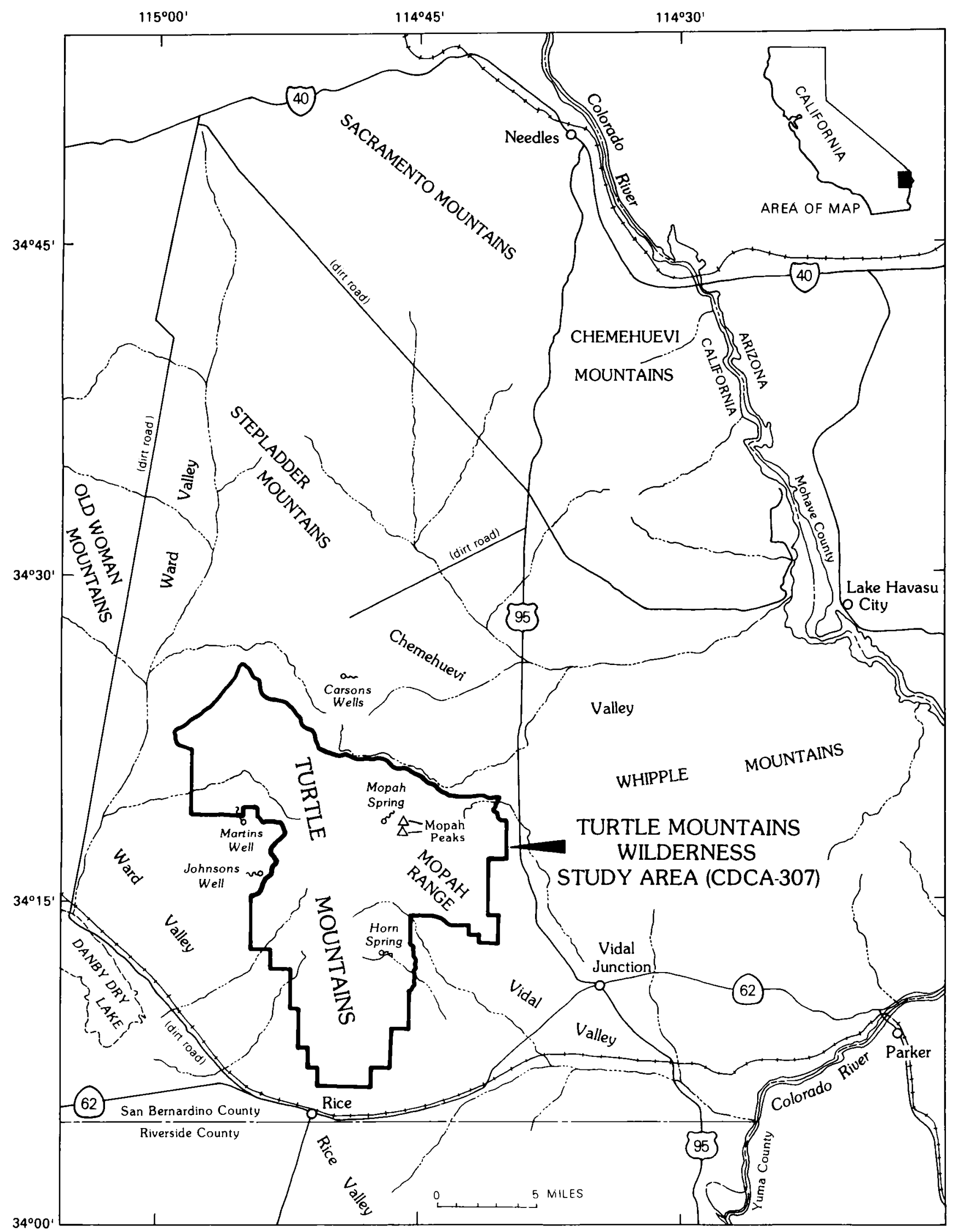

Figure 1. Index map showing location of Turtle Mountains Wilderness Study Area, San Bernardino County, California. 
produced about 1,200 tons of copper ore and small amounts of gold, silver, and lead between 1913 and 1954. Recently, mining activity has focused on prospecting for lode gold in the basement rocks and placer gold in alluvium along the east side of the wilderness study area. A small operation has intermittently produced onyx. Leases (or lease applications) for oil and gas exploration cover most of the alluvial lowlands adjacent to the wilderness study area.

\section{Mineral Resources and Mineral Resource Potential}

Identified resources of gold and silver exist adjacent to (within $1.5 \mathrm{mi}$ ) the west side of the wilderness study area; nearby parts of the study area contain gold and silver occurrences. The south-central part of the wilderness study area contains copper-zinc-silver-gold occurrences.

The presence of argillically altered rocks, extensive ironoxide staining, quartz veins, sulfide minerals, and streamsediment geochemical anomalies indicates that broad areas surrounding the recognized deposits of precious (gold, silver) and base (copper, zinc) metals are favorable for gold and silver mineralization. These areas are underlain mainly by mixed gneisses that occur between plutons and lie along several regional east- to northeast-trending aeromagnetic anomalies. Geologic, mineralogic, and geochemical evidence suggest that mineralization occurred prior to and during Miocene time. Six areas in the south-central and northwestern study area have high resource potential, two areas around them have moderate resource potential, and one area in the southwest corner has low resource potential for undiscovered low-grade, possibly large-tonnage deposits of gold, silver, and byproduct copper, lead, zinc, molybdenum, and tungsten (fig. 2). Most of the study area has low resource potential for lode gold and silver, and the entire area has low resource potential for placer gold and silver. Small gold-bearing veins are possible targets for small mining operations. Alluvium in the northwest part of the study area has moderate resource potential for placer gold and silver.

Perlite and ornamental stone (onyx marble and opal) are present in small quantities in the wildemess study area, and there is a low potential for undiscovered resources of these commodities. There is low resource potential for manganese, uranium and thorium, pegmatite minerals, and oil and gas. Sand and gravel occur in quantity but have no unique qualities and are readily available in nearby areas outside the wilderness study area.

\section{INTRODUCTION}

This mineral resources study is a joint effort by the U.S. Geological Survey and the U.S. Bureau of Mines. The history and philosophy of such joint mineral surveys of U.S. Bureau of Land Management Wildemess Study Areas were discussed by Beikman and others (1983). Mineral assessment methodology and terminology were discussed by Goudarzi (1984). Resources are classified according to the system described by U. S. Bureau of Mines and U. S. Geological Survey (1980). See appendixes for the definition of levels of mineral resource potential and certainty of assessment and the resource/reserve classification. Studies by the U. S. Geological Survey are designed to provide a reasonable scientific basis for assessing the potential for undiscovered mineral resources by determining geologic units and structures, possible environments of mineral formation, presence of geochemical and geophysical anomalies, and applicable ore-deposit models. The U. S. Bureau of Mines evaluates identified resources at individual mines and known mineralized areas by collecting data on current and past mining activities and by field examination of mines, prospects, claims, and mineralized areas.

The Turtle Mountains Wilderness Study Area (CDCA307) is in the Mojave Desert of southeastern San Bernardino County, Calif., about $35 \mathrm{mi}$ south-southwest of Needles, Calif., and $25 \mathrm{mi}$ west of Parker, Ariz. (fig. 1). The study area consists of approximately 105,200 acres and includes most of the southern two-thirds of the Turtle Mountains and all of the adjoining Mopah Range. Access from the east and south is provided by U.S. Highway 95 and California Highway 62 . A few jeep trails penetrate the study area.

The Turtle Mountains and the Mopah Range are adjoining elongate mountain ranges that trend north to northwest. Elevations above sea level range from $1,120 \mathrm{ft}$ in Rice Valley at the south margin of the wilderness study area to $4,313 \mathrm{ft}$ in the central Turtle Mountains. The rugged mountains are flanked by broad alluviated valleys that slope gently away from the mountains. The area is arid and lacks perennial streams. Intermittently, water may be found at Mopah Spring in the east part of the study area and in several shallow wells such as at Horn Spring.

A previous evaluation of mineral resource potential of the Turtle Mountains and Mopah Range was presented by Vredenburgh (1982).

\section{Methods of Investigation}

From 1981 to 1983, the U.S. Bureau of Mines investigated mines and prospects in and near the study area, as well as the regional mining history. Mining-claim locations were obtained from county records, and land-status plats were acquired from the U.S. Bureau of Land Management. In some cases, claimants provided a mine prospectus, engineering reports, and historical and exploration information. The U.S. Bureau of Mines files provided pre-1954 mineral production data. Mining-claim locations were examined in the field, and accessible workings were mapped and surveyed by the tape and compass method. Four hundred and three chip, select, stream-sediment, and grab samples collected from workings and mineralized areas were analyzed by fire assay for gold and silver and by atomic absorption for barium, copper, molybde- 


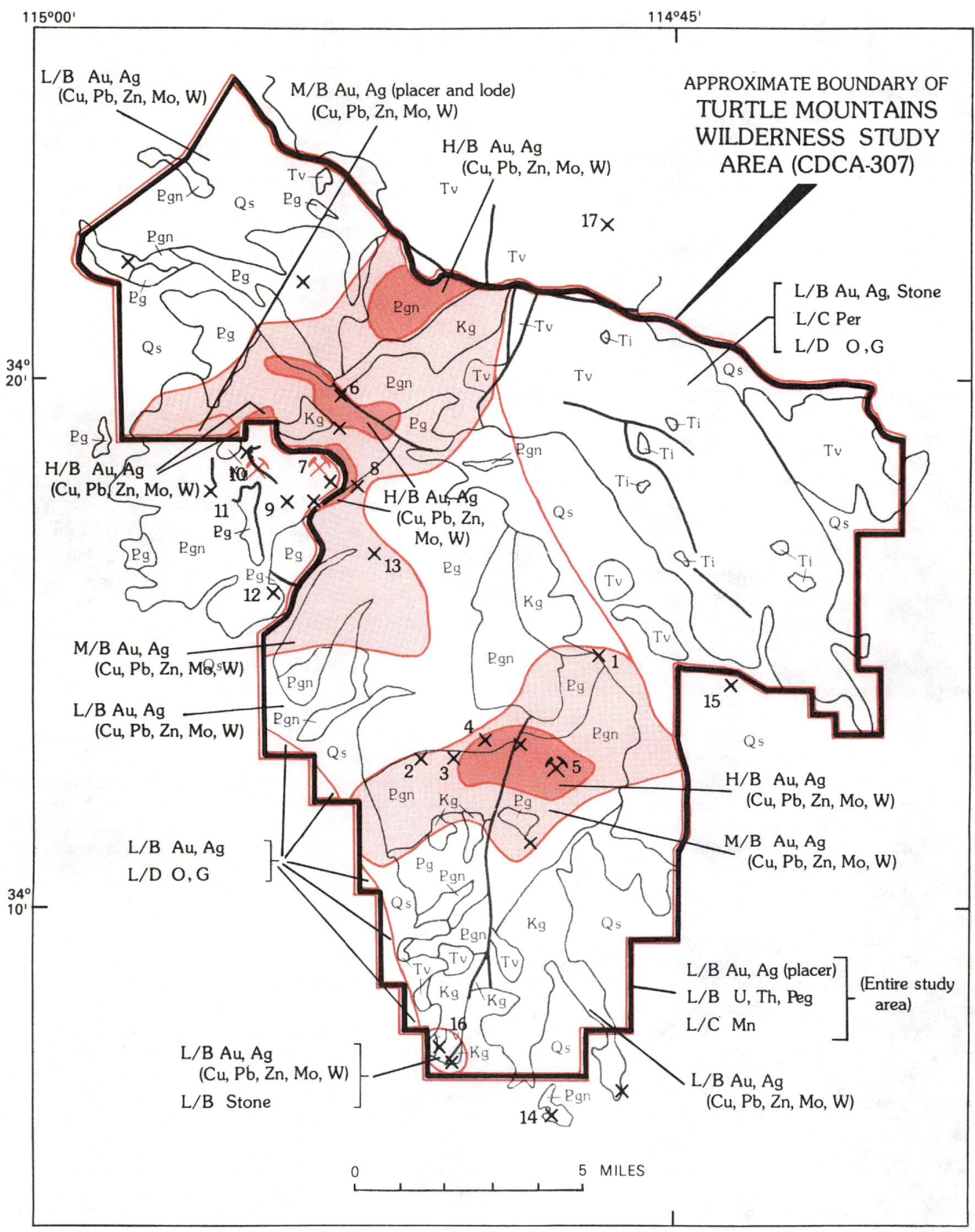

Figure 2. Mineral resource potential, general geology, and mines, prospects, and claims of Turtle Mountains Wilderness Study Area, San Bernardino County, California. 


\section{EXPLANATION}

Area with high mineral resource potential
Area with moderate mineral resource potential
Area with low mineral resource potential
$3 x^{7}$ Mine with identified resource-See table 1 for
description
See appendixes for definition of levels of mineral resource potential and
certainty of assessment and for resource/reserve classification

Commodities

$\begin{array}{clcl}\mathrm{Ag} & \text { Silver } & \text { Peg } & \text { Pegmatite } \\ \mathrm{Au} & \text { Gold } & \text { Per } & \text { Perlite } \\ \mathrm{Cu} & \text { Copper } & \text { Stone } & \text { Ornamental Stone } \\ \mathrm{Mn} & \text { Manganese } & \mathrm{Th} & \text { Thorium } \\ \mathrm{Mo} & \text { Molybdenum } & \mathrm{U} & \text { Uranium } \\ \mathrm{O}, \mathrm{G} & \text { Oil and gas } & \mathrm{W} & \text { Tungsten } \\ \mathrm{Pb} & \text { Lead } & \mathrm{Zn} & \text { Zinc }\end{array}$

Mines and prospects

$\begin{array}{lll}\text { Helen Gene No. 1 claim } & 10 . & \text { Grand Reef claims } \\ \text { Unnamed prospect } & 11 . & \text { Black Turtle claims } \\ \text { Unnamed prospect } & 12 . & \text { Wet Mine claims } \\ \text { Unnamed prospect } & 13 . & \text { Silica claim } \\ \text { Virginia May mine } & 14 . & \text { Unnamed prospect } \\ \text { Turtle claims } & 15 . & \text { Angel claim } \\ \text { Sablon mine } & 16 . & \text { S and W claims } \\ \text { Unnamed prospect } & 17 . & \text { Craik perlite } \\ \text { Peg-Mina and Mina-Peg } & & \text { deposit }\end{array}$
claims

Geologic map units

Surficial deposits (Quaternary)

Volcanic and sedimentary rocks (Tertiary)

Intrusive rocks (Tertiary)

Granitoid rocks (Cretaceous)

Granite, diorite, and augen gneiss (Proterozoic)

Mixed gneisses (Proterozioc)

\section{Contact}

Fault

$\lambda^{5}$ Mine-See table 1 for description

$x^{8}$ Prospect-Numbered where description appears in table 1

Figure 2. Continued. num, lead, tin, and zinc. In addition, selected samples were analyzed by 40 -element optical emission spectroscopy to reveal any unsuspected mineral occurrences. McDonnell (1984) published the U.S. Bureau of Mines analytical data and mapping; complete analytical data for all samples are available for public inspection at the U.S. Bureau of Mines, Intermountain Field Operations Center, Building 20, Denver Federal Center, Denver, Colorado 80225.

The U.S. Geological Survey conducted field and laboratory studies of the wilderness study area from 1981 to 1984 . These comprised aeromagnetic and gravity studies by R.W. Simpson and T. Gage, geochemical sampling and analysis by H.V. Alminas and further interpretations by K.A. Howard and J.E. Nielson, Landsat mapping of altered areas by Raines (1983), potassium-argon geochronology by J.K. Nakata, and geologic mapping by K.A. Howard, C.M. Allen, J.K. Nakata, T.T. Fitzgibbon, Paul Stone (crystalline rocks), R.W. Hazlett, J.E. Nielson, R.D. Tumer (volcanic rocks), and H.G. Wilshire (surficial deposits).

The aeromagnetic study was based on a regional draped aeromagnetic survey, for which east-west flight lines were spaced 0.5 miles apart (U.S. Geological Survey, 1981). For the gravity survey, approximately 110 new gravity stations were measured to supplement existing data. Bouguer gravity and isostatic residual-gravity maps were prepared to study the anomalous gravimetric values with the effects of topography removed. The resulting gravity highs and lows generally indicate rocks of high and low density, respectively, in the subsurface (Nettleton, 1971). Limonitic surface staining was mapped at a scale of $1: 250,000$ by using specially processed Landsat images supplemented by rapid reconnaissance field checks (Raines, 1983). Geochemical samples were collected from 231 stream-sediment sites and 97 outcrop sites. The sediments, heavy-mineral concentrates from the sediments, and the rock samples were analyzed using semiquantitative geochemical methods, and the bedrock samples were also analyzed quantitatively for antimony, arsenic, bismuth, cadmium, gold, and zinc. The results are reported by Detra and others (1983). In addition, the samples were examined to detemine mineralogy, and oxalic-acid leachates of most of the stream-sediment samples were also analyzed semiquantitatively to detect metals attached to iron-oxide coatings on weathering products. Samples dated by the potassium-argon method were analyzed for $\mathrm{K}_{2} 0$ by P. R. Klock, D. Vivit, L. F. Espos, and S. T. Neil, and were analyzed for isotopic argon in by J.K. Nakata at the U.S. Geological Survey in Menlo Park, Calif.

\section{Acknowledgments}

Appreciation is extended to Larry Vredenburgh, U.S. Bureau of Land Management geologist, for his knowledge and assistance. Mine claimants Martin Garo and Jim Hunt provided claim information and mine-engineering data. G.D. Baskin, A.M. Bielski, and Anthony Popish of the U.S. Bureau 
of Mines assisted with field studies. H.G. Wilshire, C.M. Allen, T.T. Fitzgibbon, and R.D. Turner of the U.S. Geological Survey all contributed to the geologic mapping; David Detra supervised the geochemical analysis; and Gary Raines performed the remote-sensing study. Geologic mapping by Carr and others (1980) was used for the southern Mopah Range. We thank Paul Stone, Howard Wilshire, Jocelyn Peterson, and William Bagby for reviewing drafts of this report.

\section{Geologic Setting}

Tertiary volcanic rocks are exposed in the Mopah Range in the eastern part of the study area, and Proterozoic and Mesozoic crystalline basement rocks are exposed in the Turtle Mountains in the western part of the study area (fig. 2). The rocks record a long and complex geologic history beginning nearly two billion years ago. In Early Proterozoic time, sedimentation and volcanism were followed by plutonism and high-grade regional metamorphism. More plutons (and, subsequently, dikes) were intruded in Middle Proterozoic time. After a long period of geologic stability in Paleozoic time, the rocks were intruded by plutons and dikes during the Cretaceous. Volcanism, shallow intrusion, and pervasive normal faulting occurred during the Miocene. Much of the alteration and mineralization in the area can be related to these Miocene events. Since the Miocene, the area has not experienced much tectonic activity, and erosion has resulted in the formation of alluvial aprons and pediment veneers on the range flanks.

\section{APPRAISAL OF IDENTIFIED RESOURCES}

By John R. McDonnell, Jr. U.S. Bureau of Mines

\section{Mining History}

Prospecting and mining for gold, silver, and copper have been reported in and near the Turtle Mountains Wilderness Study Area (table 1; pl. 1; fig. 2). Vredenburgh and others (1981) suggested that gold and copper mining in this area may have begun as early as 1862 . According to an unpublished Sablon mine prospectus, Mexican citizens opened the mine (adjacent to the wilderness study area, fig. 2, No. 7) in the 1880 's and used mules to transport hand-picked, high-grade gold ore to the railroad for shipment to a smelter/refinery.

Robert A. Martin worked the Sablon mine and claimed the Grand Reef property (near the study area, fig.2, No. 10) during the 1930's. He began prospecting in the area now known as Martins Well prior to 1917 and continued to mine and prospect the area until his death in the 1950's
(Vredenburgh, 1982). He used primitive concentrating methods utilizing an arrastra, sluices, and hand panning and sustained himself by selectively mining high-grade ore (Shannon, 1972). U.S. Bureau of Mines records indicate that in 1934 and 1935 Martin produced 9 tons of ore that contained $21 \mathrm{oz}$ gold, $95 \mathrm{oz}$ silver, $15 \mathrm{lb}$ copper, and $134 \mathrm{lb}$ lead.

A reconnaissance examination of the Grand Reef claims by Duval Corporation in 1962 led to detailed geological, geophysical, and geochemical studies augmented by soil sampling and the drilling of four test holes in 1968 and 1969 (R.H. Helming, Duval Corporation, written commun., 1982). According to Shannon's report (1972), these studies indicate that a potentially exploitable gold deposit exists on the Grand Reef claims.

In about 1900, several mining camps were established in the northern Turtle Mountains near Carsons Wells, about $5 \mathrm{mi}$ north of the wilderness study area. In 1906, the camps were part of the Sunrise mining district (Vredenburgh and others, 1981).

During this period, the Horn Copper mine, now known as the Virginia May mine (within the study area, fig. 2, No. 5) was activated. U.S. Bureau of Mines records show that sporadic production from this mine between 1913 and 1954 totaled 1,178 tons of ore containing $92,280 \mathrm{lb}$ copper, $307 \mathrm{oz}$ silver, and $3 \mathrm{oz}$ gold.

The Craik perlite deposit, $2 \mathrm{mi}$ north of the wildemess study area, was investigated during the 1950's. Although the deposit is large and the perlite has been thoroughly tested, it has been mined only for testing purposes (Wright and others, 1953, p. 64).

Since the deregulation of gold prices by the U.S. Government in 1972, mining and exploration activity in and near the study area has increased. As of 1982, this activity included (1) gold and silver prospecting on the Turtle claims by the claimant, Martin Garo, (2) haulage-road construction and planned production at a group of properties including the Grand Reef claims and the Sablon mine by Minerals Group, Inc., (3) claiming and investigation of the Virginia May mine (Horn Copper) property by Jense McCormick and Mine Development Corporation, (4) the establishment of a small mill in the Carsons Wells area, (5) exploration for placer gold deposits in the Chemehuevi Valley northeast of the study area and along the eastern study-area boundary, (6) small-scale placer gold mining on the Angel claim by claimant Robert Cross, and (7) intermittent production of onyx from the $S$ and W claims.

\section{Identified Resources and Mineralized Areas}

The U.S. Bureau of Mines investigated 17 mineral occurrences in and near the wilderness study area (fig. 2; table 1). These included copper-zinc-silver-gold occurrences within the study area near Hom Spring, and gold-silver occurrences near Martins Well, within and along the western boundary of 
the study area. A small onyx deposit lies along the southern boundary of the study area, and a perlite deposit may possibly extend into the northeastern part of the wilderness study area. Sand and gravel are abundant in valleys and washes.

\section{Metallic Minerals}

\section{Horn Spring Area}

Copper and zinc occurrences in the vicinity of Horn Spring are all within the south central part of the wilderness study area (fig. 2; table 1, Nos. 1-5). The host rocks are Proterozoic gneiss, quartzite, and schist, which have been intruded by Mesozoic plutons (Wright and others, 1953; Howard and others, 1982). "Copper ore minerals, principally chrysocolla with lesser cuprite, chalcopyrite and chalcocite, together with abundant silica have been deposited along fractures and have formed small replacement bodies along fault zones..." in the host rock (Wright and others, 1953, p. 64).

Numerous workings in the Horn Spring area intersect and follow enriched fault zones; in some cases, extensive stopes have been developed. In 1983, the principal workings, which included the Virginia May mine (fig. 2, No. 5), were covered by the Mac claims and were actively being examined by Jense McCormick and Mine Development Corporation.

Samples taken in the vicinity of Horn Spring contained as much as 18.5 percent copper, 10.9 percent zinc, $0.056 \mathrm{oz}$ gold per ton, and $0.8 \mathrm{oz}$ silver per ton. Of the 195 samples collected, 55 contained more than 1 percent copper, 26 contained more than 1 percent zinc, and 11 contained at least $0.005 \mathrm{oz}$ gold per ton and $0.02 \mathrm{oz}$ silver per ton (McDonnell, 1984, p. 70-89). Insufficient data preclude the calculation of grade and tonnage, but field observations and analytical data (McDonnell, 1984,p. 70-89) indicate that a copper-zinc-silver-gold deposit may extend beyond the mine area.

\section{Martins Well Area}

Mineral occurrences of gold and silver in the vicinity of Martins Well are within and near the west-central boundary of the wilderness study area. The mineralized area is in the unsurveyed northwest sections of T. 2 N., R. 20., the southwest sections of T. 3 N., R. 20 E., and the NE 1/4 sec. 1, T. 2 N., R. 19 E. (fig. 2, Nos. 6-13). The host rocks are mainly Proterozoic gneiss cut by intrusive bodies of diorite, andesite, and rhyolite. Gold, silver, and minor copper mineralization occurred along veins that coincide with faults and fractures.

Field observations and analytical data indicate the presence of a gold-silver occurrence in the Turtle claims area (McDonnell, 1984). Highly fractured, altered and leached granite gneiss exhibiting some veining is exposed in outcrops and workings on the claims (fig. 2, No.6). Samples collected at the exposure by the claimant and by U.S. Bureau of Mines personnel contained some gold and (or) silver.

Northeast-trending shear zones and veins in gneiss are exposed in outcrops and workings about 2 mi east to southeast of Martins Well near the Sablon mine (fig. 2, Nos. 7 and 8). These structures occur both inside and outside the wilderness study area. An unpublished Sablon mine prospectus reports that 25 samples were collected "at random along the vein to make up a pilot leaching sample of 1 ton ... the overall assay average was $3.7 \mathrm{oz} \mathrm{Au}$ and it leached out $2.9 \mathrm{oz}$..." U.S. Bureau of Mines personnel collected 20 samples along about $950 \mathrm{ft}$ of a vein in the Sablon mine workings and seven samples from nearby workings. Twelve of these samples contained from 0.042 to $0.486 \mathrm{oz}$ gold per ton, and seven samples contained from 0.2 to $0.7 \mathrm{oz}$ silver per ton. Using sample data from the main workings at the Sablon mine, McDonnell (1984, p. 8-9) calculated inferred resources of about 5,400 tons of ore containing $0.22 \mathrm{oz}$ gold per ton; minor silver occurs with the gold, but the values were too dispersed to determine grade and tonnage for these occurrences. This small-tonnage, low-to moderate-grade gold-silver resource is outside the wilderness study area boundary, but field observations and geologic evidence indicate that the mineralized structure extends an unknown distance into the wilderness study area. If the mineralization continues along the northeastern strike of the structure, then the resource may also extend into the wilderness study area.

About $1.5 \mathrm{mi}$ southwest of the Sablon mine, $0.5 \mathrm{mi}$ outside the wilderness study area, northeast- and northweststriking faults cut the host gneiss and are exposed in workings near the Peg-Mina and Mina-Peg claims (fig. 2, No. 9). The faulted gneiss contains quartz veins, lenses, and stringers, calcite stringers, and abundant hematite staining. Of ten samples collected, one contained $0.034 \mathrm{oz}$ gold per ton, another contained $1.1 \mathrm{oz}$ silver per ton, three contained more than 1 percent lead, and minor zinc was detected in four samples (McDonnell, 1984, p. 55). The extent of the structures beyond the workings could not be determined due to ground cover, but the northeast-striking faults have similar geologic characteristics and may be related to shear zones exposed in the Sablon mine area.

The largest known mineral occurrence in the Martins Well area is on the Grand Reef claims (fig. 2, No. 10). Claims extend from Martins Well, $6,000 \mathrm{ft}$ southeastward outside of the wilderness study area. Shannon (1972) described the "reef" (mineralized area) as a 1,000-ft-wide and 3,000-ft-long zone of hydrothermally altered siliceous rock with a network of quartz and calcite veins in a series of Precambrian gneisses. He wrote as follows:

For the most part, the ore minerals occur in the veins but there is some dispersion of values through the "reef" itself. The several minerals occur either separately or in combination. Gold and silver constitute the principle metal values with lesser amounts of lead, copper, molybdenum, and flourite. Gold is native; silver occurs both isomorphously 
with lead and in discrete sulph-antimonides. Galena and cerussite are the lead minerals; molybdenum occurs as the lead molybdenate, wulfenite. Secondary copper minerals, malachite and chrysocolla, were noted along with some tenorite.

Shannon also reported that there is a possible relation between vein density and a fault that defines the eastern margin of the "reef".

Numerous workings have been excavated in the faulted, fractured, and veined gneiss on the Grand Reef claims. Of 91 samples collected from the workings by U.S. Bureau of Mines personnel, 21 contained 0.005 to $0.872 \mathrm{oz}$ gold per ton, and 11 contained 0.5 to $3.4 \mathrm{oz}$ silver per ton (McDonnell, 1984, p. 57$65)$.

Shannon concluded that the Grand Reef claims have a potential for a large-tonnage, low-grade operation with reserves of as much as $10,000,000$ tons of ore containing $0.05 \mathrm{oz}$ gold per ton (a potential gross value of $\$ 225$ million dollars with gold at $\$ 450 / \mathrm{oz}$ ) or as much as $2,000,000$ tons of ore containing $0.10 \mathrm{oz}$ gold per ton. Shannon's report states that after his initial studies he recognized the merits of the prospect and took a working interest in it when proffered. U.S. Bureau of Mines field studies and analytical data corroborate Shannon's conclusion that a low-grade gold-silver resource occurs on the Grand Reef claims, and they indicate that a part of the deposit may extend into the wilderness study area.

About $1 \mathrm{mi}$ southwest of the Grand Reef claims $(1 \mathrm{mi}$ outside the wilderness study area), a copper-mineralized gouge zone and specularite veins are exposed in workings on the Black Turtle claims (fig. 2, No. 11). Abundant malachite, chrysocolla, and garnet are found in the gouge material between two northeast-striking nearly parallel faults that cut diorite and gneiss. U.S. Bureau of Mines personnel collected six samples from or between the two faults; five samples contained at least 0.50 percent copper, two contained 0.026 and $0.028 \mathrm{oz}$ gold per ton, and one contained $0.03 \mathrm{oz}$ silver per ton (McDonnell, 1984, p. 66-67). The extent of the mineralized zone could not be determined due to ground cover, but the presence of a copper-gold-silver occurrence in the claim area is indicated. The specularite veins are related to a nearby pod of specularite that appears to be several hundred feet in diameter. The specularite occurrence is thought to correlate with the hydrothermal alteration and mineralization found at the Grand Reef claims.

Sheared and altered gneiss is exposed by workings near Johnsons Well, about $0.5 \mathrm{mi}$ west of the wilderness study area (fig. 2, No. 12). Analytical data show only one of eight samples contained detectable precious metal $(0.4 \mathrm{oz}$ silver per ton) (McDonnell, 1984, p. 12). The altered gneiss has the same geologic characteristics noted at previously discussed mineral occurrences, but assay data indicate that the mineralization was weak or possibly absent in this area.

Inside the wilderness study area, at a site that had been covered by the Silica claim (fig. 2, No. 13), several workings were excavated along gneiss-diabase and gneiss-granite con- tacts. Of six surface samples along the exposed contacts, two samples contained 0.042 to 0.020 oz gold per ton (McDonnell, 1984, p. 12-13). Field observations and analytical data indicate the presence of a gold occurrence within the wilderness study area at the Silica claim site.

\section{Placer Claims}

At the time the U.S. Bureau of Mines conducted its field investigation for this report, the Angel claim (fig. 2, No. 15) was the only recorded placer claim near the wilderness study area. The claimant had sunk a shaft and reported that he had recovered some gold. U.S. Bureau of Land Management records, dated September 1983, show new claim blocks located along the eastern and northeastern boundary of the wilderness study area.

\section{Nonmetallic Minerals}

Since about 1977, onyx has been mined intermittently from the S and W claims (fig. 3, No. 16) (Vredenburgh, 1982). The site is in Tertiary sandstone in contact with Cretaceous granodiorite; the workings comprise numerous bulldozer cuts and several pits. During the field examination by U.S. Bureau of Mines personnel, no onyx exposures were located amid the broken and disrupted ground. Minor amounts of gold and silver were detected in two samples of Tertiary sandstone (McDonnell, 1984).

At the Craik perlite deposit 2 mi north of the wildemess study area (fig. 2, No. 17), perlite occurs as flows as thick as several feet and is associated with rhyolite flows, tuff beds, and tuffaceous sedimentary rocks. The deposit has been mined only for test samples, and analytical data were not available (see Wright and others, 1953, p. 65). Within the study area, perlite occurrences are smaller than at the Craik perlite deposit.

Federal oil and gas leases and lease applications cover the valleys that surround the Turtle Mountains. No oil and gas shows are known to have occurred in the area, but the U.S. Geological Survey (Calzia and others, 1979) has classified the surrounding Rice, Vidal, Ward, and Chemehuevi valleys as prospectively valuable for oil and gas resources.

Sand and gravel are abundant in poorly sorted alluvium around the flanks of the mountains and in dry washes. However, economic constraints limit usage to local demand, and similar materials are plentiful in nearby, more accessible areas outside the wilderness study area.

\section{Recommendations for Future Work}

The U.S. Bureau of Mines investigation of the Turtle Mountains Wilderness Study Area revealed four areas that should be considered for detailed geochemical and 


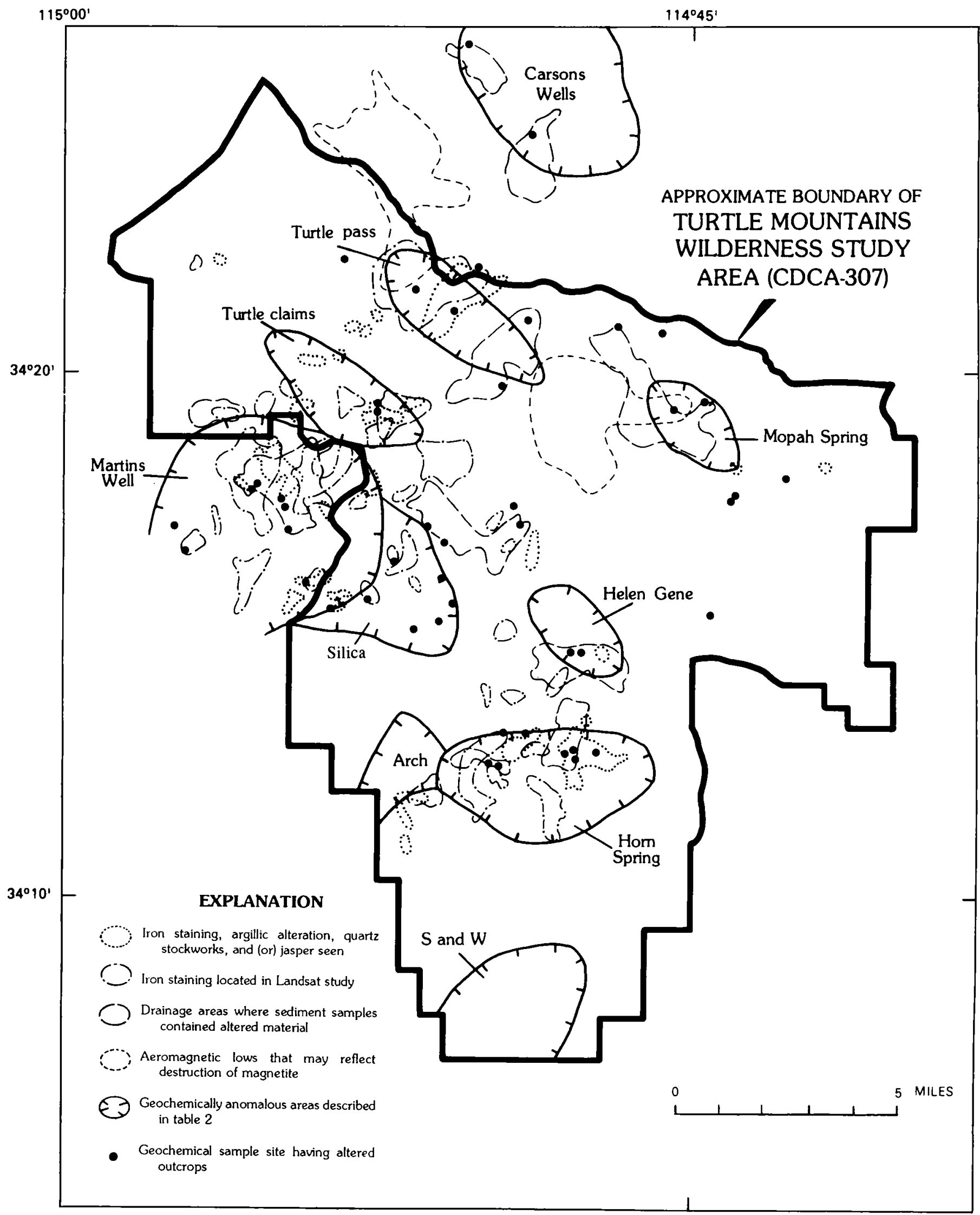

Figure 3. Turtle Mountains Wilderness Study Area showing areas of altered rocks and geochemically anomalous areas. Iron-stained areas of Landsat studies were identified as areas of propylitic or argillic alteration by Raines (1983); locations are approximate. 
geophysical surveys to define possible drilling targets: (1) the Horn Spring area, to define the extent and concentration of mineralization exposed in workings; (2) the Sablon mine area, to determine how far the mined structure extends into the wilderness study area and to define any mineral concentrations that occur along it; (3) the Grand Reed claim area, to determine how the mineralized area extends into the wilderness study area; and (4) the S and W claim area, to determine the extent of the gold and silver occurrences.

\section{ASSESSMENT OF MINERAL RESOURCE POTENTIAL}

By Keith A. Howard, Jane E. Nielson, Robert W. Simpson, Richard W. Hazlett, Henry V. Alminas, and John K. Nakata U.S. Geological Survey

\section{Geology}

Previous studies showed that the rocks of the Turtle Mountains Wilderness Study Area (fig. 2; pl. 1) consist of Proterozoic and Mesozoic metamorphic and plutonic rocks, in addition to Tertiary plugs and volcanic and sedimentary rocks (Chesterman, 1949; Bishop, 1963; Armstrong and Suppe, 1973; Woodward-McNeill and Associates, 1974; Hathaway and Kuniyoshi, 1975; Carr and others, 1980; Howard and others, 1982). Faults cut these rocks, and Quaternary alluvial aprons flank the ranges.

The Turtle Mountains and Mopah Range lie within a region characterized by high- and low-angle extensional faults of middle Tertiary age. The ranges may compose part of a breakaway zone from which fault blocks slid eastward along a low-angle detachment fault that is exposed to the east in the Whipple Mountains (Davis and others, 1980; Howard and others, 1982). It has been suggested that this fault underlies (in a synform) both the Turtle Mountains and the Mopah Range (Howard and others, 1982; Frost and Okaya, 1986). Most fault blocks in the Turtle Mountains and Mopah Range tilt westward, as evidenced by Tertiary strata dipping $10^{\circ}-45^{\circ}$ (Carr and others, 1980; Woodward-McNeill and Associates, 1974; Howard and others, 1982).

\section{Rock Units}

The Mopah Range contains mainly Tertiary volcanic rocks. Proterozoic and Mesozoic crystalline basement rocks locally capped by Tertiary rocks are exposed in that part of the Turtle Mountains within the study area.

Much of the pre-Tertiary crystalline basement terrane is composed of Proterozoic gneiss. A unit of mixed gneisses is made up largely of fine-grained granite gneiss and leucocratic granite gneiss, both containing garnet, lesser quantities of amphibolite, and patches of metasedimentary gneiss derived from argillaceous quartzite, conglomerate, and pelite. The mixed gneisses form two major northeast-trending outcrop areas separated by a large pluton of granodiorite augen gneiss (fig. 2; pl. 1). Both the augen gneiss and the leucocratic gneiss locally contain pegmatite bodies. All gneissic rocks are complexly deformed; foliation most commonly is steep and strikes east to northeast. This strike imposes a structural grain to which subsequent Cretaceous plutons have conformed. The gneissic rocks record a polyphase history of plutonism and metamorphism superimposed on an original sequence of immature sedimentary and volcanic rocks (Howard and others, 1982). These events are undated in the Turtle Mountains; they all may be part of an Early Proterozoic crust-forming event $(1,700-1,800 \mathrm{Ma})$ documented elsewhere in the southwestern United States (Silver and others, 1977).

Granite and diorite plutons of known or inferred Middle Proterozoic age intrude the gneisses. The largest of these, a coarse-grained granite pluton in the northwestern part of the study area, belongs to a group of similar plutons that occur over a wide area in the southwestern United States (Anderson, 1983). A diorite, gabbro, and homblendite pluton in the southern part of the study area was tentatively considered to be Jurassic in age by Howard and others (1982); however, on the basis of new potassium-argon dating (J.K. Nakata, unpub. data), we now consider it to be Proterozoic.

Proterozoic diabase dikes, inferred to be about 1,100 $1,200 \mathrm{Ma}$, intrude the older rocks as gently south-dipping sheets. They are particularly prevalent in the large coarsegrained granite pluton in the northwest part of the study area, where white quartz veins commonly occur along the dike margins. Five miles north of the study area, at Carsons Wells, similar veins have been mined for gold; they occur only in the basement rocks and do not cross the pre-Miocene-Miocene unconformity.

Cretaceous granodiorite plutons intrude Proterozoic rocks in the southern and central parts of the wilderness study area. The plutons contain a few aplite and pegmatite dikes; numerous aplite dikes intrude the country rock near small satellite granodiorite plutons in the southwestern part of the wilderness study area. Potassium-argon ages of 93 to $106 \mathrm{Ma}$ on biotite and hornblende from three localities suggest that the plutons are mid-Cretaceous in age (Howard and others, 1982). A Cretaceous diorite pluton with satellitic andesite dikes in the Martins Well area has an age of 68-87 Ma, by potassiumargon dating of biotite and hornblende from three localities (J.K. Nakata, unpub. data). This pluton is elongate and discontinuous along the northeast-trending regional grain of the Proterozoic gneiss that it intrudes. Plagioclase from a nearby Proterozoic diabase dike has retained some of its original argon, yielding an apparent potassium-argon age of $674 \mathrm{Ma}$ (J.K. Nakata, unpub. data); this suggests that the diorite magma did not greatly heat the diabase country rock and was emplaced at a relatively shallow depth. 
A third intrusive suite of probable Cretaceous age occurs as a swarm of north- to northeast-trending quartz-porphyry dikes, each several miles long. The quartz porphyry is hypabyssal granite to rhyolite characterized by phenocrysts of quartz and, locally, mica and feldspar. The quartz-porphyry dikes cut Proterozoic rocks and the Cretaceous diorite and granodiorite plutons. The dikes resemble quartz-porphyry dikes that emanate from Cretaceous granite plutons in the nearby Stepladder and Sacramento Mountains.

Miocene rocks, estimated to be 3,000-5,000 ft thick in the Mopah Range, include (1) volcanic flows, tuff, and breccia ranging in composition from basalt to rhyolite, (2) necks of rhyodacite, (3) dikes of silicic and basaltic rock, and (4) a minor amount of sedimentary rocks (Hazlett, 1986). The Miocene rocks form a lower volcanic sequence and a thinner, unconformably overlying capping-basalt sequence. The lower sequence is composed mainly of rhyodacitic and andesitic lava flows and breccias. It also includes basalt, trachyandesite, rhyolite, landslide breccia, basement-rockclast conglomerate, sandstone, siltstone, claystone, and limestone. The capping sequence consists of subalkaline and alkaline basalt flows and minor arkosic sandstone and conglomerate. Potassium-argon dating of the volcanic rocks indicates that the lower sequence was erupted about $18-22 \mathrm{Ma}$ and the capping-basalt sequence was erupted about 14-18 Ma (Howard and others, 1982; Nielson and Turner, 1986; Hazlett, 1986). Deeply weathered crystalline rocks locally underlie the Tertiary rocks.

Five subvolcanic rhyodacitic plugs, each $0.2-0.5 \mathrm{mi}$ across, and numerous north-northwest-trending mafic to felsic dikes show that the area of the Mopah Range was a Miocene volcanic center. Some dikes cut exposed basement rocks. Most of the exposed Tertiary intrusive bodies are in the middle and upper parts of the Tertiary section and thus represent the latest intrusive activity in the development of the volcanic field (Hazlett, 1986).

Post-faulting estuarine mudstone and sandstone of the Pliocene Bouse Formation are present beneath alluvial fans east of the study area (H.G. Wilshire, oral commun., 1984) and may also underlie alluvial fans on the east, south, and west margins of the study area. Quaternary alluvium forms dry stream beds and alluvial fans around the range flanks. Alluvial fill within the wilderness study area is generally thin, as suggested by nonlinear mountain fronts and the presence of inselbergs and incised pediments.

\section{Faults}

Miocene faults impart a pronounced north- to northwesttrending structural and topographic grain to the study area. Local thin mylonite zones represent older faults, thought to be of Late Cretaceous (one zone cuts a Cretaceous granodiorite pluton) and Late or Middle Proterozoic age (a potassiumargon minimum age of $619 \mathrm{Ma}$ was obtained on amphibole in mylonitized diabase). The Miocene faults extensively dissect the volcanic rocks of the Mopah Range and, less extensively, the basement rocks of the Turtle Mountains. Miocene flows and strata between the faults generally dip $10^{\circ}-45^{\circ}$ southwest.

The tilting and faulting accompanied Miocene volcanism, as indicated by an angular unconformity between the capping-basalt sequence and the underlying lower sequence. Similar faulting and tilting is bracketed stratigraphically between about 25 to $14 \mathrm{Ma}$ in nearby ranges (for example, Davis and others, 1980). Pliocene or younger faults may be present locally in the eastern Mopah Range (Carr and others, 1980). Most of the faults strike north to northwest and dip east to northeast. They exhibit normal displacement; a few are lowangle normal faults dipping $30^{\circ}$ or less. A fault that forms the footwall of the mineralized gneiss at the Grand Reef claims dips $30^{\circ}-35^{\circ}$ east, and slickensides, gypsum fibers, and disrupted marker layers show normal slip to the southeast. A subhorizontal fault forming the hanging wall of the same mineralized rocks crops out as as a silicified microbreccia ledge with northeast-trending striae on its polished surface. A Miocene age is likely for these faults because they resemble low-angle faults of known Miocene age in ranges to the east (for example, see Davis and others, 1980).

Northeast-trending faults cut the basement rocks near Martins Well and the Sablon mine. One of these faults shows lateral displacement related to Tertiary extension, but others may be older. Some of these faults are mineralized, and the northest-trending zone in which they occur coincides with geochemical and aeromagnetic anomalies.

A long topographic lineament bisects the basement exposures along a south-southeast trend from Martins Well to the southeast comer of T. 2 N., R. 20 E. (pl. 1). This lineament, which coincides in places with broad geochemical anomalies, is marked by Tertiary faults in places and may represent a fracture pathway for mineralization. A parallel zone of numerous down-to-the-east normal faults separates the basement terrane from the Mopah Range to the east. Quartz veins follow some of the Tertiary faults where they cut pre-Tertiary basement rocks, and chalcedony is common along faults in the volcanic rocks. Specular hematite is common along faults and associated breccia dikes in the basement terrane.

\section{Altered Rocks}

Altered rocks crop out in many areas of the Turtle Mountains. Areas containing altered rocks independently identified in geologic, geochemical, and remote-sensing surveys are outlined in figure 3 . For the remote-sensing survey, Raines (1983) mapped areas with limonitic alteration from Landsat images by using a color-ratio technique. Combined with reconnaissance field checks and semiquantitative analyses of grab samples, the remote-sensing study indicated the presence of several areas of propylitically and argillically altered rocks in the Turtle Mountains, including argillically 
altered rocks in the Martins Well-Johnsons Well area, and an area 4-6 mi northeast of Martins Well, here informally called the "Turtle pass" area (fig. 3). All three surveys generally indicate the presence of two major northeast-trending belts of altered rocks in the basement terrane (fig. 3).

Iron-oxide staining, quartz veins, and oxides and sulfides of iron and copper are commonly seen in the basement rocks; in many cases, these features are localized along Miocene normal faults (fig. 3). Iron-stained rocks include the youngest basement rocks, namely Cretaceous plutons and quartz porphyry dikes. Calcedony, jasper, and limonite occur locally along faults in the Mopah Range in the Miocene rocks. Mineralized quartz veins and iron staining occur in basement rocks along north-trending normal faults that displace Tertiary basalt several hundred feet in the south part of the area (near the boundary between R. $20 \mathrm{E}$. and R. $21 \mathrm{E}$., T. $1 \mathrm{~N}$.). Specularite-matrix breccia about $200 \mathrm{ft}$ thick occurs along a major northwest-trending fault at the Turtle claims (fig. 2, No. 6); the fault is Cenozoic in age, as it truncates the projected trace of an erosional outlier of Miocene strata $1 \mathrm{mi}$ to the northeast. Gneiss in a house-sized zone along a nearby parallel fracture is completely altered to soft white clay and sericite. Iron-oxide-stained, silicified, and mineralized gneiss at the Grand Reef claims is bounded below and above by lowangle faults that closely resemble in style the faults of known Miocene age in many nearby ranges. The association of altered areas with Miocene faults suggests that alteration occurred contemporaneously with the Miocene faulting. No major structural or thermal events that could have caused the alteration are known to have occurred since the early Miocene.

Evidence of an older alteration event is present locally, where Late Cretaceous diorite truncates two small altered zones ( 1 and 3 mi northeast of Martins Well). Furthermore, mineralized northeast-trending faults in the Sablon mine area and variously oriented mineralized structures at the Virginia May mine cannot definitely be related to Tertiary faulting and may be older.

Radiometric dating provides evidence that Miocene alteration in the basement rocks was at low temperature (less than about $250-300^{\circ} \mathrm{C}$.) or that the heat did not penetrate the host rocks outside the altered zones. This conclusion follows from the discovery that dated basement rocks give pre-Tertiary apparent ages (Howard and others, 1982; J.K. Nakata, unpublished data). These ages were determined on several samples of biotite, plagioclase, and homblende, using the potassium-argon method, and on one sample of zircon, using the fission-track method. If Tertiary heating had been great, younger ages would be expected.

In mountain ranges east of the study area, pervasive potassium metasomatism accompanied the Miocene faulting and volcanism so that many of the Tertiary rocks were enriched in potassium and depleted in sodium (Pike, 1983). This effect was minimal in the wilderness study area, where analyzed basement and volcanic rocks yield normal ratios of potash to soda, generally near or less than 1.0 (unpub. data of
R.W. Hazlett, J.E. Nielson, K.A. Howard, and S.E. Shaw). Deposits of hydrous silica are common in volcanic rock units and along faults of the Mopah Range. Some mafic flows and airfall tuffs of the lower volcanic sequence contain green and yellow celadonitic clay.

\section{Geochemistry}

The regional geochemical survey delineates anomalous parts of the study area where there is evidence of mineralizing processes that concentrated metals and associated elements. The anomalies were detected in bedrock samples and in heavy-mineral concentrates and oxalic-acid leachates of seived (minus-80-mesh) stream sediments.

The stream-sediment samples were collected at 231 sites (Detra and others, 1983), mostly in first- and second-order drainages. Outcrop samples were collected from 97 sites as composited chip samples (Detra and others, 1983). The high density of sediment-sampling sites allows contouring of element concentrations, and the resulting contour maps generally show high values clustered in certain areas.

Table 2 lists elements concentrated in the geochemically anomalous areas outlined on figure 3. Two levels of anomalies are indicated on table 2: distinctly concentrated ( $x$ symbol) for areally focused anomalies that tend to be well above background levels, and indistinctly concentrated (symbol) for dispersed anomalies that are less high above background values. The two most geochemically conspicuous areas are the Martins Well and Horn Spring areas. These geochemically anomalous areas, and most others indicated in figure 3 and table 2, enclose zones of altered rocks that have been prospected or mined. Chalcopyrite and pyrite were identified in stream sediments from some areas (table 2), and fluorite and topaz were found to be widespread in the stream sediments.

Elements concentrated in the anomalous areas include the following: barium, bismuth, boron, copper, lanthanum, lead, molybdenum, thorium, tungsten, and zinc in stream sediments; bismuth, gold, and mercury in outcrop samples; and beryllium, chromium, cobalt, copper, lanthanum, lead, manganese, molybdenum, silver, strontium, yttrium, and zinc in oxalic-acid leachates. The leachate data were obtained by leaching the minus-80-mesh stream sediments with 5 percent oxalic acid, then analyzing the leachates semiquantitatively using an emission-spectrographic method. This technique detects metals attached to iron-oxide coatings on weathering products and can reveal leakage halos around mineralizing systems.

The results of the geochemical sampling and analyses suggest that broad areas of the basement rocks in the Turtle Mountains were affected by an epithermal mineralization system (or systems) that concentrated gold, silver, copper, lead, zinc, tungsten, molybdenum and other elements. Geochemically anomalous stream samples correlate closely with the presence of garnet in the samples. The garnet probably is 
derived mainly from the unit of mixed gneisses that underlies the most intensely altered areas; this unit contains abundant metamorphic garnet of Proterozoic age.

The Horn Spring anomalous area (fig. 3 ) is characterized by tightly grouped map patterns of concentrations of most of the elements listed in table 2. Mixed gneisses underlie this area.

The Martins Well anomalous area (fig. 3), most of which lies outside the wilderness study area, includes Johnsons Well and the Sablon mine. Underlain primarily by mixed gneisses, augen gneiss, and diorite, this area is characterized by concentrations of most of the elements listed in table 2. Lead present in the leachate samples is anomalously concentrated in the center of the anomalous area. High concentrations of molybdenum, strontium, and zinc in the leachates, thorium and tungsten in the nonmagnetic sediment concentrates, and barium, lanthanum, and lead in the magnetic fraction occur in a more widespread pattern, forming an anomaly halo around the central area of mines and prospects.

Areas designated as Helen Gene, Arch, and Silica all contain anomalous concentrations of several metals and leachate silver (table 2). The Turtle claims area (fig. 3 ) is anomalous in several elements.

Northeast of the Turtle claims is another anomalous area where a jeep trail crosses the Turtle Mountains over an area of low badlands eroded on altered gneiss; in this report, this area is called "Turtle pass". The Turtle pass area shows many of the same geochemical characteristics as the Martins Well and Horn Spring areas, except that there are few leachate anomalies present (table 2). The anomalies at Turtle pass tend to be clustered, as at Horn Spring, and not in halos, as at Martins Well. Gold was detected at $0.05 \mathrm{ppm}$ in one rock sample each from the Turtle pass and Martins Well areas (Detra and others, 1983). Anomalous concentrations of lead in nonmagnetic heavy minerals define a northeast-trending belt that links the Martins Well, Turtle claims, and Turtle pass areas; this belt is underlain by mixed gneisses.

Mercury in rock samples shows a concentration in the southwest part of the study area in and near the area designated "S and W" on figure 3 (see table 2). This area is underlain by Cretaceous granodiorite, Proterozoic gneiss, and Miocene basalt and clastic rocks.

In the volcanic terrane of the Mopah Range and northern Turtle Mountains, geochemical patterns are difficult to generalize or to interpret. Concentrations of tungsten and leachate yttrium are conspiculously low. Many other analyzed elements, especially in leachates, have higher average concentrations and are less consistently areally focused than in the crystalline basement terrane. Compared to the basement terrane, metals in the volcanic terrane tend to be prominent in leachates and in magnetic minerals (mainly oxides); concentrations of lead in nonmagnetic minerals (mainly sulfides) are low. It is unclear if the elevated concentrations of many elements in the volcanic terrane provide evidence for mineralization or, instead, represent high background values unrelated to mineralization. The presence of garnet in stream- sediment concentrates throughout the volcanic terrane presents a further difficulty, because garnet does not occur in the volcanic rocks. Garnet found in streams draining the volcanic terrane is likely to be derived from Miocene interbeds of basement-clast sedimentary rocks, which may also contribute other minerals and metals to the stream samples, that were not derived from the volcanic terrane.

The Carsons Wells area in the volcanic terrane has higher concentrations of copper in nonmagnetic minerals and of several elements in the leachate (table 2) than does most of the volcanic terrane. The drainage area consists mostly of highly faulted silicic-to-intermediate Miocene volcanic rocks and overlaps an area of old gold mines and claims in pre-Tertiary basement rocks. Although high-background geochemical values are assumed for the volcanic terrane, the Carsons Wells area (fig. 3) still shows metal concentrations that are distinctly elevated and therefore may be an area of volcanic rocks in which mineralizing processes occurred.

An area where silicic flows and plugs occur around Mopah Spring (fig. 3) contains unfocused anomalies of several metals, and some stream-sediment samples contain fluorite (table 2). Chalcopyrite and anomalous barium, copper, and lead were found in an area between the Mopah Spring and Turtle pass areas (fig. 3); the samples may contain detritus from both the volcanic and basement terranes. At the south end of the Mopah Range volcanic terrane, gold was detected in a rock sample at a concentration below the limit of determination (0.05 ppm; Detra and others, 1983). Geochemical results from the Mopah Range are inconclusive as to whether the rocks were affected by mineralization processes similar to those in the basement terrane.

In conclusion, areas of mineralized rocks in the study area contain anomalous concentrations of antimony, arsenic, barium, beryllium, bismuth, copper, gold, lanthanum, lead, molybdenum, silver, thorium, tungsten, zinc, and locally mercury. Lead and other metals detected in the volcanic terrane are concentrated in magnetic minerals (mainly oxides), whereas lead in the basement terrane is concentrated in nonmagnetic minerals (mainly sulfides). This pattern conforms to a tiered model of a Tertiary mineralizing system in which sulfide minerals were deposited in basement rocks at greater depth. Also in accord with a tiered mineralizing system, anomalous tungsten is common only in the basement terrane, whereas anomalous zinc is more concentrated in the volcanic terrane.

\section{Geophysics}

\section{Aeromagnetic Data}

Aeromagnetic highs occur over exposures of Proterozoic augen gneiss and Proterozoic and Cretaceous mafic igneous rocks. Smaller aeromagnetic highs occur in a northwesttrending belt over the volcanic rocks of the Mopah Range and 
northern Turtle Mountains and their subsurface extensions to the southeast and northwest.

Aeromagnetic lows commonly occur over sedimentfilled valleys, altered areas in which magnetite has been destroyed, and reversely magnetized volcanic rocks. Two sharp aeromagnetic lows over Tertiary volcanic rocks in the wilderness study area (fig. 3) may indicate the presence of altered rocks at depth. The southern aeromagnetic low approximately coincides with the area between the Turtle pass and Mopah Spring geochemical areas, where stream sediments contain chalcopyrite and concentrations of barium, copper, and lead. Other less prominent aeromagnetic lows (not shown in fig. 3) occur over the vicinities of the Sablon mine and the Virginia May mine. These lows may reflect unmapped lithologic variations. However, if these lows reflect the alteration observed at the mine sites, then similar small lows elsewhere in the wilderness study area may indicate analogous conditions. The location of some of these lows agrees with the altered areas (fig. 3) defined by other techniques. Some smaller areas with lows over basalt may reflect reversely magnetized volcanic rocks.

Aeromagnetic gradients in the study area generally trend northwest and northeast. A very prominent northeast-trending aeromagnetic lineament passes through the study area in the Martins Well area. This lineament, which extends for at least $60 \mathrm{mi}$ across the eastern half of the Needles $1^{\circ}$ by $2^{\circ}$ quadrangle (U.S. Geological Survey, 1981), suggests the presence of a fundamental fracture or other structure in the basement. Such a structure, if it exists, could serve as a pathway for mineralizing fluids. In the Turtle Mountains, this lineament is most clearly expressed by the alignment of magnetic highs over bodies of relatively magnetic Cretaceous diorite parallel to the grain of Proterozoic foliation (pl. 1). South of these highs, a belt of lows extends northeastward from the Sablon mine area and possibly reflects an extension of the altered rocks at the mine into the study area.

\section{Gravity Data}

A broad north-northwest-trending area of isostatic residual-gravity highs coincides with exposures of Proterozoic rocks in the Turtle Mountains. The highest values occur over the southern Turtle Mountains where Proterozoic diorite and other dense mafic rocks are exposed. The two bounding gradients are interpreted to indicate increased depth to basement rocks on either side of the gravity high, and suggest the presence of structures on which the top of the basement terrane is lowered at least 1,000 feet. The gravity gradient on the southwest side of the gravity high lies several miles southwest of the present range front, mostly outside the study area; the gradient suggests the presence of a fault on this side of the range beyond a pediment. The steepest part of the gradient on the northeast side of the gravity high lies along the southwest flank of the Mopah Range and may reflect downdropping along a structural breakaway zone at the head- wall of a large detachment fault (Davis and others, 1980; Howard and others, 1982). The volcanic rocks of the Mopah Range generally coincide with gravity lows, the values of which suggest a thickness of low-density volcanic and sedimentary rocks in excess of $1,000 \mathrm{ft}$ under parts of this range.

\section{Radiometric Surveys}

An aerial radiometric survey over the region (Geodata International, Inc., 1979) detected no unusual concentrations of uranium. Alluvium in eastern Ward Valley, along the westcentral side of the study area, has two to three times the normal thorium content for the region and is slightly enriched in uranium, according to the results of the aerial survey. Vredenburgh (1982) reported that a second aerial radiometric survey encountered a high potassium anomaly over the Mopah Peaks and potassium, thorium, and uranium anomalies at the mouth of the Martins Well wash. The reason for the presence of these anomalies is not known.

Field-scintillometer readings several times the background level were recorded for Proterozoic coarse-grained granite in a foliated body $1 \mathrm{mi}$ south of the study area near Rice and in a 3-ft-wide dike $1 \mathrm{mi}$ west of Johnsons Well. Fault gouge in an adit at the Grand Reef claims has radioactivity several times higher than background levels.

\section{Mineral and Energy Resource Potential}

Several geologic environments in the wilderness study area may be favorable for the occurrence of mineral resources (pl. 1). We conclude that (1) parts of the study area have high and moderate mineral resource potential for gold, silver, and associated copper, lead, zinc, molybdenum and tungsten and (2) the area has low mineral resource potential for manganese, uranium and thorium, perlite, pegmatite minerals, ornamental stone, and oil and gas. See appendixes for the definition of levels of mineral resource potential and certainty of assessment.

\section{Gold, Silver, and Associated Metals (Lode)}

There is high mineral resource potential for undiscovered gold and silver with byproduct copper, lead, zinc, molybdenum, and tungsten in parts of the study area, with a certainty level of B. Broader regions within the study area have moderate resource potential for gold and silver with byproduct copper, lead, zinc, molybdenum, and tungsten, with a certainty level of B. Most of the study area has low resource potential for gold and silver, with a certainty level of $B$; in the basement terrane this low resource potential applies also to byproduct copper, lead, zinc, molybdenum and tungsten. 
Deposit Description

Fine-grained free(?) gold and gold and silver minerals occur along veins or are disseminated in silicified and (or) altered basement rocks, especially where the rocks are fractured or brecciated by Tertiary normal faulting. Most Tertiary faults dip east or northeast, so that hydrothermal fluids likely migrated upward from eastern sources. Some mineral occurrences are along older(?) faults or near a major undisplaced northwest-trending fracture lineament. Mineral occurrences are concentrated in belts of Proterozoic mixed gneisses between plutons; these belts coincide with aeromagnetic lineaments, lie parallel to some mineralized faults, and may reflect large deep-seated structures. Evidence of minerals is also found in Proterozoic diabase, granite, and augen gneiss. All Miocene and older rocks are possible hosts.

The largest known gold occurrence is at the Grand Reef claims in the Martins Well area adjacent to the wilderness study area. Mineralization occurred in a structural plate of gneiss bounded by two low-angle normal faults; the plate is extensively brecciated, bleached, and silicified and is as thick as several hundred feet. Rocks in this area contain appreciable amounts of gold according to Shannon (1972). A high scintillometer reading in gouge near the base of the plate indicates local uranium and (or) thorium concentration. Ironoxide staining, brecciation, geochemical anomalies, and a few old prospects occur along another low-angle fault zone in the southwestern part of the wilderness study area (Arch area, fig. 3; unsurveyed sections 9 and 16, T. 1 N., R. 20 E.). One of the drainages here has eroded a small natural arch through the iron-stained fault breccia. Such arches may be of historical interest, as old legends place a Lost Arch gold mine in the Turtle Mountains region (for example, see Johnson, 1964).

Gold and copper are associated with specular hematite in steeply dipping fault breccias and breccia veins in basement rocks. Specularite-rich fault breccia is as thick as $200 \mathrm{ft}$ near the Turtle claims, and specularite-matrix breccia veins are from two inches to several feet thick in the Black Turtle and Grand Reef claims areas. The geologic setting of these deposits suggesțs that they are the result of hydrothermal deposition and oxidation of materials leached from depth and circulated along faults and fractures during Miocene extensional faulting.

In some basement rocks, quartz veins containing oxides and sulfides follow many of the Tertiary faults, and many of these veins have been prospected. Rocks near some of the faults are iron-oxide stained and argillically altered; locally they are completely altered to white clay.

Steep northeast-trending faults and veins in Proterozoic gneiss are similarly enriched with gold and silver along the west side of the wilderness study area in the Sablon mine and Peg-Mina claim areas. The northeast orientation suggests that the mineralized structures may be pre-Tertiary in age because most known Tertiary faults strike northwest. At the Virginia May mine, the mineralized veins and faults have a variety of orientations (McDonnell, 1983), and it is unknown whether they are Teriary or older.

Two broad areas of basement rocks in the wilderness study area are marked by diffuse, rust-colored iron staining, geochemical anomalies, the occurrence of sulfides, silicic fault breccias and (or) stockworks of small quartz veins, and low topographic relief resulting from erodible altered and (or) brecciated rocks; both areas contain small prospects. The northern area (Turtle pass) of low badlands lies 3 to $5 \mathrm{mi}$ northeast of Martins Well and is $1-2 \mathrm{mi}^{2}$ in area. The southern area lies $1 \mathrm{mi}$ west of the Virginia May mine and occupies about $0.3 \mathrm{mi}^{2}$. Geochemical data indicate the presence of metal concentrations in both areas. Tertiary faults occur in both areas, but the broad altered areas are not directly related to individual faults. The diffuse areal pattern of alteration in these two areas suggests hydrothermal systems that may be related to hidden intrusive bodies.

\section{Deposit Age and Type}

Conflicting data suggest Miocene or pre-Miocene ages, thus at least two periods of mineralization seem likely. A preMiocene age is suggested by (1) the concentration of altered rocks, mineral occurrences, and geochemically anomalous areas in basement rocks, especially along belts of mixed gneisses and along northeast-trending faults, and (2) a preMiocene age for veins at Carsons Wells and in the northwest part of the study area. Early Miocene mineralization is suggested by alteration of, and mineral occurrences along, Miocene faults in basement rocks, by the presence of geochemical anomalies in streams draining Miocene rocks near Carsons Wells, and by uncommon altered areas elsewhere in the Miocene volcanic terrane. Evidence is discussed below, from oldest to youngest, for five possible deposit types or events: Proterozoic strata-bound or metamorphic deposits, pre-Miocene (Proterozoic?) quartz veining, Cretaceous intrusion halos, Miocene epithermal deposits related to geothermal activity and faulting, and Miocene hot-spring-type deposits.

Altered, mineralized, and geochemically anomalous rocks are aligned along northeast-trending belts of mixed gneisses. This alignment indicates that deposits may be lithologically controlled; minerals may have been concentrated originally in Proterozoic stratabound or metamorphic deposits. Later events (for instance, during the Miocene) might have redistributed the metals. Stratabound sulfide deposits are reported to occur in Early Proterozoic rocks $60 \mathrm{mi}$ east of the wilderness study area at the Antler mine (Stensrud and More, 1980). Those deposits are associated with amphibolites and metasedimentary rocks not unlike some of the rocks in the mixed-gneisses unit of the Turtle Mountains. No stratabound deposits have been recognized in the Turtle Mountains, but two observations suggest their possible existence. (1) Mine tailings at the Virginia May copper mine include sillimanite gneiss derived from a pelitic sedimentary protolith; some prospect shafts appear to target this rock type, 
suggesting that this relatively rare rock in the Turtle Mountains may be host to strata-related mineralization in the mine area. (2) The mineral deposits at the Virginia May mine are associated with spinel (Wright and others, 1953, p. 64); zinc spinel commonly characterizes strata-bound sulfide deposits in similar high-grade metamorphic Proterozoic rocks (Sheridan and Raymond, 1982).

Gold apparently was deposited at Carsons Wells in preMiocene quartz veins that follow the borders of Proterozoic diabase sheets. The association of veins and diabase is seen throughout the northwestern part of the study area in areas mapped as Proterozoic granite, where two exploratory shafts were sunk along these veins. The veins at Carsons Wells were mined for free gold associated with pyrite and chalcopyrite (Tucker and Sampson, 1943). The age and tectonic environment of veining is not known, but it may be as old as Middle Proterozoic. The veins associated with Proterozoic diabase and granite differ in orientation from mineralized veins elsewhere in the study area and are mostly whiter, lacking iron staining; these differences suggest that they represent a separate mineralizing event.

Cretaceous intrusions and their wall rocks provide a possible environment for mineralizing systems. Copper and gold-silver deposits believed to be associated with Cretaceous intrusions are reported from the Whipple Mountains and the Mohave Mountains to the east of the study area (Marsh and others, 1982; Light and others, 1983). They occur in allochthonous Proterozoic rocks inferred to have moved east in Tertiary time from positions originally close to the Mopah Range. Hydrothermal alteration may have accompanied intrusion of the Cretaceous(?) quartz-porphry dikes in the Turtle Mountains, as suggested by the presence of carbonate deposits 1-3 ft thick that flank both sides of one of these dikes near the Peg-Mina claims. Late Cretaceous diorite intrudes iron-stained rocks in the northem part of the study area; the area of observed alteration is only about an acre, but a magnetic low coincident with it is about $1 \mathrm{mi}^{2}$. The belt of mineralized areas that includes Martins Well, the Turtle claims, and the Turtle pass area is centered on a northeasttrending body of Cretaceous diorite, suggesting a possible relation of mineralization to Cretaceous intrusion. A geochemically anomalous area (designated Helen Gene on figure 3) coincides with the contact of a Cretaceous granodiorite pluton and possibly is related to the pluton. Insufficient data are available to either deny or strongly support a Cretaceous age of mineralization in the study area.

The presence of abundant Miocene extensional faults, and several silicic subvolcanic necks and dikes in the Mopah Range, suggests a magmatic-hydrothermal environment that can explain much of the observed alteration and mineralization in the basement terrane, especially that along Tertiary faults. The mineralized low-angle fault plate at the Grand Reef claims area fits a geologic model in which epithermal minerals are deposited in brecciated rocks above a Tertiary detachment fault during extensional faulting (Wilkins and Heidrick, 1982). Miocene epithermal mineralization, con- centrated in the basement terrane, is the preferred explanation for most observed mineral concentrations in the study area.

Whether or not Miocene mineralization affected Miocene rocks in the Mopah Range is less clear. The Miocene rocks are less conspicuously altered than the basement rocks. Sediments from which geochemically anomalous samples were collected near Carsons Wells drain volcanic rocks that directly overlie mineralized basement rocks and may record metal concentrations remobilized from basement deposits. The anomalous area drains directly toward placers being explored for gold in Chemehuevi Wash to the east. The gold detected in a rock sample from the south end of the Mopah Range and the gold and silver detected by the U.S. Bureau of Mines in Tertiary sandstone at the $S$ and $W$ claims in the southwest part of the study area suggest mineralizing processes in Miocene rocks. Hot-spring-type, low-grade gold deposits might be expected in the Miocene volcanic terrane if it was affected by the same mineralizing system as the basement terrane, but at a higher structural level. Any gold and silver occurrences (if present) in the Miocene rocks are likely to be disseminated and fine grained and could be associated with jasper or chalcedony. East of the Mopah Peaks in an area of about an acre, outcrops of jasper are associated with faults. Mercury and other geochemical anomalies, chalcopyrite in stream sediments, and Tertiary travertine vein fillings provide evidence for possible hot-spring activity in basement rocks in a broad area including the $\mathrm{S}$ and $\mathrm{W}$ claims.

\section{Assessment}

The following criteria were used to assign the potential for undiscovered lode metals in the study area. The criteria were not used statistically but provided the framework for determination of mineral resource potential.

1. Identified resources or mineral occurrences are present, and gold, silver, copper, and lead have been produced.

2. Fractured crystalline basement rocks are present.

3. Host rocks contain quartz and minor chalcedony veins and some stockworks and show extensive iron staining, silicification, bleaching, and argillic alteration.

4. Samples contain anomalous concentrations of copper, lead, zinc, tungsten, molybdenum, silver, beryllium, thorium, barium, and locally gold, antimony, bismuth, and mercury.

5. Sulfides (mainly pyrite and chalcopyrite) are abundant; topaz and fluorite are also present.

6. Specularite is present in fault and vein breccias.

7. Heat sources are evident in the form of nearby Tertiary silicic, intermediate, and basaltic intrusions. Host rocks were at depths of about 0.5 to $2 \mathrm{mi}$ during Miocene tectonism, magmatism, and alteration.

8. Host rocks are located near or on major east- to northeasttrending aeromagnetic anomalies. Local aeromagnetic lows over some areas may indicate destruction of magnetite by alteration. 
Two broad areas of basement rocks have moderate potential, with certainty level B, for lode resources of gold and silver with byproduct copper, lead, zinc, molybdenum, and tungsten (fig. 2; plate 1). The widespread geochemical anomalies, faulting, and evidence of alteration and mineralization are the basis for assigning this potential to these two areas. The northern area encloses Martins Well and the southern area encloses Horn Spring.

Within these two broad areas are local areas of high mineral resource potential for the same commodities (fig. 2; pl. 1). A high mineral resource potential (certainty level B) for gold, silver, and byproduct copper, lead, zinc, molybdenum, and tungsten is assigned in the northern belt to the most intensely altered areas, which all contain detectable gold and exhibit other geochemical anomalies. These high potential areas are the Martins Well-Sablon mine areas, the Turtle claims area, and the Turtle pass area 5 mi northeast of Martins Well (where prospects but no mines are known). On the basis of geochemical anomalies, altered rocks, and sulfide-mineral occurrences, the central, most intensely altered part of the southern belt, including the Virginia May mine, also has high mineral resource potential (certainty level B) for gold, silver, and byproduct copper, lead, zinc, molybdenum, and tungsten.

Other parts of the basement terrane in the study area have similar but more scattered geochemical anomalies and evidence of alteration and are permissive environments for epithermal deposits. They have low mineral resource potential, with a certainty level B, for the same commodities as above. The Mopah Range and southwestern Turtle Mountains are permissive environments for hot-spring-type gold deposits and have low mineral resource potential for gold and silver, with a certainty level B.

Lode deposits, if present, may yield low-grade and largetonnage ores. Detailed geochemical sampling, followed by drilling in the area, would be required to identify likely targets. Large-tonnage gold deposits are present in geologic environments similar to that in the study area at the Mesquite and Pichaco mines in the lower Colorado River area, Califomia, about 70-90 mi south of the wilderness study area (Wilkins, 1985). In addition to possible large-tonnage low-grade deposits, small deposits may occur along specific veins, such as those mined in the past.

\section{Gold and Silver (Placer)}

The presence of known and potential lode gold and silver suggests that placer concentrations may occur downstream. Gold may be fine, inasmuch as none was identified in mineralogic studies of the stream-sediment samples. Placer prospects for gold and silver were being explored privately in 1982 in a large area of Chemehuevi Wash 5-10 mi northeast of the wilderness study area (Anonymous, 1982). The alluvium at the placer claims drains an area of Tertiary volcanic and subvolcanic intrusive rocks near Carsons Wells. These rocks interfinger with units within the wilderness study area in the Mopah Range. It is not clear whether placer gold and silver reported in Chemehuevi Wash may be derived from the Tertiary rocks or from Proterozoic host rocks in the adjacent Carsons Wells area of small gold mines, which is only separated from the headwaters of the placer drainage area by a low drainage divide. The placer gold and silver reportedly occur in alluvium as well as in an underlying clayey silt; the clayey silt probably correlates with the Pliocene Bouse Formation that crops out in nearby Chemehuevi Valley. Bedrock sources in the wilderness study area could provide similar alluvial placers. Placer gold is also reported from the Angel claim located in alluvium downstream from both the volcanic and basement rocks of the study area.

A moderate potential for placer mineral resources of gold and silver (certainty level B) is assigned to alluvial deposits in Martins Well wash, downstream from part of the Grand Reef claims, because the lode claims contain identified gold-silver resources. Elsewhere in the wilderness study area, the mineral potential for placers is considered to be low (certainty level B), but the environment is permissive on the basis of low, moderate, and high potential for lode gold and silver resources. Reports of actual production in the future from placers in Chemehuevi Wash would provide a basis for reassessing the mineral potential in the study area.

\section{Manganese}

Small manganese deposits are associated with Tertiary faulting in nearby ranges; except for a minor occurrence at the $S$ and $W$ claim, no such deposits are verified in the wilderness study area. The mineral resource potential for manganese in the study area is low, with a certainty level of $\mathrm{C}$.

\section{Uranium and Thorium}

Although Proterozoic granite in the study area locally gives high scintillometer readings, neither it nor similarly radioactive Middle Proterozoic granite $40 \mathrm{mi}$ to the northwest in the Marble Mountains is known to contain or be associated with uranium- or thorium-bearing occurrences. Radioactive fault gouge at the Grand Reef claims probably reflects local mobilization of uranium and (or) thorium during Tertiary epithermal mineralization and is judged to have little significance for potential resources. A broad thorium anomaly in alluvium on the west-central side of the wilderness study area is of unknown origin but possibly relates to concentration of allanite, monazite, or other minerals derived from Early Proterozoic granodiorite augen gneiss. High concentrations are unlikely. The mineral resource potential for uranium and thorium in the study area is low, with a certainty level of B. 


\section{Perlite}

Perlite (hydrated volcanic glass) occurs in silicic volcanic flows in the Mopah Range. The most favorable environment is in rhyodacite flows at the stratigraphic top of the lower volcanic sequence. East of Mopah Peaks, these flows are glassy, tens of meters thick, and contain patches of perlite. The perlite deposits are smaller than those at the Craik perlite deposit, 1-2 mi north of the wilderness study area, which was prospected but never mined commercially. The resource potential for perlite in the volcanic terrane is low, with a certainty level of $C$.

\section{Pegmatite Minerals}

Pegmatite dikes of Proterozoic and Cretaceous age could contain beryl or other useful minerals. Proterozoic granite, leucocratic granite gneiss, granodiorite augen gneiss, and Cretaceous granodiorite all have associated pegmatites. None is known to contain minerals of commercial interest. Streamsediment samples contain topaz and fluorite, minerals that are sometimes associated with pegmatite minerals. However, a post-pegmatite Tertiary age is suggested for these minerals by their presence in samples from the volcanic terrane as well as from the basement terrane. The mineral resource potential for pegmatite minerals is low, with a certainty level of $B$.

\section{Ornamental Stone}

Ornamental travertine (onyx marble) may occur in the southwest corner of the wilderness study area where banded travertine, a few inches thick, fills cracks in Miocene sandstone and basement crystalline rocks. Onyx reportedly has been mined there on a small scale (Vredenburgh, 1982). The travertine veins probably were deposited by warm springs.

Chalcedony, jasper, opal, and agate are prospected by rockhounds in the Mopah Range (Johnson, 1964, p. 6; Vredenburgh, 1982). Opal in vugs and cracks is pervasive in rhyodacite of the Mopah Range.

On the basis of the observed sparcity and thinness of ornamental travertine and opal in the study area, the resource potential for onyx and ornamental opal in the study area is low, with a certainty level of $B$.

\section{Oil and Gas}

The wilderness study area is located along the projected trace of the Cordilleran overthrust belt, which in northern states produces petroleum. No unmetamorphosed pre-Tertiary strata that could be petroliferous are exposed in or near the Turtle Mountains, and there is very little likelihood of any at depth below thrust faults. Cenozoic sedimentary deposits of alluviated areas are another possible environment for oil or gas, but the gravity data for the wilderness study area indicate that these deposits are less than 2,000 ft thick and therefore unlikely to contain petroleum. Gravity data indicate that lowdensity materials, inferred to be Miocene supracrustal rocks, underlie the Mopah Range to a structural depth of more than $1,000 \mathrm{ft}$. These materials are mainly volcanic rocks and are unlikely to contain petroleum. The mineral resource potential for oil and gas in the Mopah Range and in alluviated areas west of the Turtle Mountains is low, with a certainty level of D.

\section{Recommendations for Future Work}

The following procedures would help to further appraise the mineral resource potential of the wilderness study area.

Sample and analyze the Bouse Formation and overlying alluvium in Chemehuevi Wash to assess the nature of reported gold and silver occurrences. Determine if Proterozoic rocks have contributed clasts to the Chemehuevi Wash placers or if all the alluvium (and reported placer gold and silver) there is derived from Tertiary rocks.

Date phyllonite at Carsons Wells (Glory Bee mine) to investigate the age and tectonic setting of pre-Miocene quartz veining.

Study the stratigraphy, petrology, and isotopic nature of Early Proterozoic mixed gneisses in order to better assess the possibility of stratabound mineralization.

Study fluid inclusions associated with Tertiary(?) alteration to investigate the nature of the mineralizing systems.

Map fault zones in greater detail; particularly, trace the Martins Well allochthon, a fault zone in Vidal Valley, and the low-angle fault system on the southwest side of the Turtle Mountains.

Perform and publish a quantitative analysis and detailed interpretation of geochemical data.

Trace the source of garnet, flourite, topaz, sulfides, and anomalous metal concentrations found in sediment samples from the Mopah Range.

Determine the jarosite-to-geothite ratio in iron-stained rocks in the most heavily altered areas to determine whether limonite is formed by oxidation of silicates or sulfides.

Determine the nature of alteration in the Mopah Range, and further investigate the extent to which metals are present and in what geologic environments.

Perform a detailed structural, mineralogical, and geochemical study of hematite deposition and potassium metasomatism as these processes relate to extensional faulting processes and possible geochemical mechanisms for concentrating gold and associated metals.

Date mineralizing event(s) by radiometric methods.

Perform thermal-history studies of basement rocks by using fission-track dating to locate possible concealed intrusive centers and to contrast and compare the geologic history of the Turtle Mountains with that of nearby ranges where deeper seated Mesozoic rocks are exposed. 


\section{REFERENCES CITED}

Anonymous, 1982, Major gold and silver deposit found near Needles: California Mining Journal, v. 52, no. 1, p. 38-39.

Anderson, J.L., 1983, Proterozoic anorogenic granite plutonism of North America, in Medaris, L.G., Jr., and others, eds., Proterozoic geology: selected papers from an international Proterozoic symposium: Geological Society of America Memoir 161, p. 133-154.

Armstrong, R.L., and Suppe, John, 1973, Potassium-argon geochronometry of Mesozoic igneous rocks in Nevada, Utah, and southern California: Geological Society of America Bulletin, v. 80, p. 1375-1392.

Beikman, H.M., Hinkle, M.E., Frieders, Twila, Marcus, S.M., and Edward, J.R., 1983, Mineral surveys by the Geological Survey and the Bureau of Mines of Bureau of Land Management Wilderness Study Areas: U.S. Geological Survey Circular 901, 28 p.

Bishop, C.C., 1963, Geologic map of California, Needles sheet: California Division of Mines and Geology scale 1:250,000.

Calzia, J.P., and others, 1979, Leasable mineral resources of the California Desert Conservation Area: U.S. Geological Survey unpublished administrative report prepared on behalf of Bureau of Land Management, California Desert Planning Staff, Riverside, Calif., 183 p.

Carr, W.J., Dickey, D.D., and Quinlivan, W.D., 1980, Geologic map of the Vidal NW, Vidal Junction, and parts of the Savahia Peak SW and Savahia Peak quadrangles, San Bernardino County, California: U.S. Geological Survey Miscelleneous Investigations Series Map 1-1126, scale $1: 24,000$

Chesterman, C.W., 1949, Dike complex in the Turtle Mountains, eastern San Bernardino County, California (abs.): Geological Society of America Bulletin, v. 60, no. 12, pt. 2, p. 1937.

Davis, G.A., Anderson, J.L., Frost, E.G., and Shackelford, T.J., 1980, Mylonitization and detachment faulting in the Whipple-Buckskin-Rawhide Mountains terrane, southeastern California and western Arizona, in Crittenden, M.D., Coney, P.J., and Davis, G.H., eds., Cordilleran metamorphic core complexes: Geological Society of America Memoir 153, p. 79-130.

Detra, D.E., Meier, A.L., and Cooley, E.F., 1983, Chemical analysis of rock, minus-80-mesh stream-sediment, and magnetic and nonmagnetic fractions from heavy-mineral concentrate samples of the Turtle Mountain Wilderness Study Area (CDCA-307), San Bernardino County, California: U.S. Geological Survey Open-file Report 83-415, 49 p.

Erickson, R.L., compiler, 1982, Characteristics of mineral deposits: U.S. Geological Survey Open-File Report 82-795, 248 p.

Frost, E.C., and Okaya, D.A., 1986, Application of seismic reflection profiles to tectonic analysis in mineral exploration: Arizona Geological Society Digest, v. 16, p. 137-152.

Geodata International, Inc., 1979, Aerial radiometric and magnetic survey, Needles National Topographic Map, California and Nevada: U.S. Department of Energy Report GJBX-114 (79), 2 volumes.

Goudarzi, G.H., 1984, Guide to mineral survey reports on public lands: U.S. Geological Survey Open-File Report 84$787,51 \mathrm{p}$.

Griffitts, W.R., 1982, Diagnostic features of fluoride-related beryllium deposits, in Erickson, R.L., Characteristics of mineral deposits: U.S. Geological Survey Open-File Report 82-795, p. 62-66.

Hathaway, A.W., and Kuniyoshi, S., 1975, Southern Turtle Mountains: a possible area of early Basin and Range structure in the southeastern Mojave Desert: Geological Society of America, Abstracts with Programs, v. 7, no. 3, p. 322-323.

Hazlett, R.W., 1986, Geology of a Tertiary volcanic center, Mopah Range, San Bernardino County, California: Los Angeles, University of Southern California, Ph.D. dissertation, $303 \mathrm{p}$.

Howard, K.A., Stone, Paul, Pernokas, M.A., and Marvin, R.F., 1982, Geologic and geochronologic reconnaissance of the Turtle Mountains area, California: west border of the Whipple Mountains detachment terrane, in Frost, E.G., and Martin, D.L., eds., Mesozoic-Cenozoic tectonic evolution of the Colorado River region, California, Arizona, and Nevada (Anderson-Hamilton Volume): San Diego, Calif., Cordilleran Publishers, p. 341-354.

Johnson, H.C., 1964, Western gem hunters atlas: Susanville, Calif., Box 288, Scenic Guides, 92 p.

Light, T.D., Pike, J.E., Howard, K.A., McDonnell, J.R., Simpson, R.W., Raines, G.L., Knox, R.D., Wilshire, H.G., and Pernokas, M.A., 1983, Mineral resource potential map of the Crossman Peak Wilderness Study Area (5-7B), Mohave County, Arizona: U.S. Geological Survey Miscelleneous Field Studies Map MF-1602-A, scale 1:48,000.

Marsh, S.P., Ridenour, James, Raines, G.L., Howard, K.A., Simpson, R.W., Moyle, P.R., Willet, S.L., and Hoover, D.P., 1982, Mineral resource potential of the Whipple Mountains Wilderness Study Area (CDCA-312), San Bernardino County, California: U.S. Geological Survey Open-File Report 82-956, 36 p.

McDonnell, J.R., Jr., 1984, Mineral investigation of the Turtle Mountains Wilderness Study Area, San Bernardino County, California: U.S. Bureau of Mines Open File Report MLA 684, $92 \mathrm{p}$.

Miller, D.M., John, B.E., Antweiler, J.C. Simpson, R.W., Hoover, D.B., Raines, G.L., and Kreidler, T.J., 1983, Mineral resource potential map of the Chemehuevi Mountains Wilderness Study Area (CDCA-310), San Bernardino County, California: U.S. Geological Survey Miscelleneous Field Studies Map MF-1584, scale 1:48,000.

Nettleton, L.L., 1971, Elementary gravity and magnetics for geologists and seismologists: Society of Exploration Geophysicists Monograph 1, $121 \mathrm{p}$.

Pike, J.E.N., 1983, Composition of Tertiary volcanic rocks, Mohave Mountains, Arizona: Geological Society of America Abstracts with Program, v. 15, no. 5, p. 304.

Raines, G.L., 1983, Preliminary map of limonitic alteration for portions of the Needles $1^{\circ} \times 2^{\circ}$ quadrangle, Arizona and California: U.S. Geological Survey Open-file Report 83 421, scale 1:250,000.

Shannon, C.W., 1972, Grand Reef gold-silver prospect: Salt Lake City, Utah, 2186 Blaine Avenue, unpublished geological engineering report, $32 \mathrm{p}$. 
Sheridan, D.M., and Raymond, W.H., 1982, Stratabound Precambrian sulfide deposits, Colorado and Wyoming, in Erickson, R.L., Characteristics of mineral deposits: U.S. Geological Survey Open-File Report 82-795, p.92-99.

Stensrud, H.L., and More, Syver, 1980, Precambrian geology and massive sulfide environments of the west-central Hualapai Mountains, Mohave County, Arizona-A preliminary report: Arizona Geological Society Digest, v. 12, p. 155-166.

Taylor, R.B., and Steven, T.A., 1983, Definition of mineral resource potential: Economic Geology, v. 78, p. 12681270.

Tucker, W.B., and Sampson, R.J., 1943, Mineral resources of San Bernardino County: California Journal of Mines and Geology, v. 39, no. 4, p. 427-549.

U.S. Bureau of Mines and U.S. Geological Survey, 1980, Principles of a resource/reserve classification for minerals: U.S. Geological Survey Circular 831, 5 p.

U.S. Geological Survey, 1981, Aeromagnetic map of the Needles $1^{\circ}$ by $2^{\circ}$ quadrangle, California and Arizona: U.S. Geological Survey Open-file Report 81-85, scale $1: 250,000$.

Vredenburgh, L.M., 1982, Geology and mineral resources of the Turtle Mountains GEM Resource Area, San Bernardino County, California: Riverside, Calif., Bureau of Land
Management Administrative Report, 34 p.

Vredenburgh, L.M., Shumway, G.L, and Hartill, R.D., 1981, Desert fever: Canoga Park, Calif., Living West Press, p. 8586.

Wilkins, Joe, Jr., 1985, The distribution of gold- and silverbearing deposits in the Basin and Range province, western United States: Arizona Geological Society Digest, v. 15, p. 1-27.

Wilkins, Joe, Jr., and Heidrick, T.L., 1982, Base and precious metal mineralization related to low-angle tectonic features in the Whipple Mountains, California, and Buckskin Mountains, Arizona, in Frost, E.G., and Martin, D.L., eds., Mesozoic-Cenozoic tectonic evolution of the Colorado River region, California, Arizona, and Nevada (AndersonHamilton volume): San Diego, Calif., Cordilleran Publishers, p. 182-203.

Woodward-McNeill and Associates, 1974, Appendices 2.5-E and 2.5-I., in Southern California Edison Company, Information concerning site characteristics, Vidal Nuclear Generating Station: Los Angeles, Calif.

Wright, L.A., Stewart, R.M., Gay, T.E., and Hazenbach, G.C., 1953, Mines and mineral deposits of San Bernardino County, California: California Journal of Mines and Geology, v. 49, nos. 1 and 2, p. 49-244. 
APPENDIXES 



\section{DEFINITION OF LEVELS OF MINERAL RESOURCE POTENTIAL AND CERTAINTY OF ASSESSMENT}

\section{Definitions of Mineral Resource Potential}

LOW mineral resource potential is assigned to areas where geologic, geochemical, and geophysical characteristics define a geologic environment in which the existence of resources is permissive. This broad category embraces areas with dispersed but insignificantly mineralized rock as well as areas with few or no indications of having been mineralized.

MODERATE mineral resource potential is assigned to areas where geologic, geochemical, and geophysical characteristics indicate a geologic environment favorable for resource occurrence, where interpretations of data indicate reasonable likelihood of resource accumulation, and (or) where an application of mineral-deposit models indicates favorable ground for the specified type(s) of deposits.

HIGH mineral resource potential is assigned to areas where geologic, geochemical, and geophysical characteristics indicate a geologic environment favorable for resource occurence, where interpretations of data indicate a high degree of likelihood for resource accumulation, where data supports mineral-deposit models indicating presence of resources, and where evidence indicates that mineral concentration has taken place. Assignment of high resource potential to an area requires some positive knowledge that mineral-forming processes have been active in at least part of the area.

UNKNOWN mineral resource potential is assigned to areas where information is inadequate to assign low, moderate, or high levels of resource potential.

NO mineral resource potential is a category reserved for a specific type of resource in a well-defined area.

Levels of Certainty

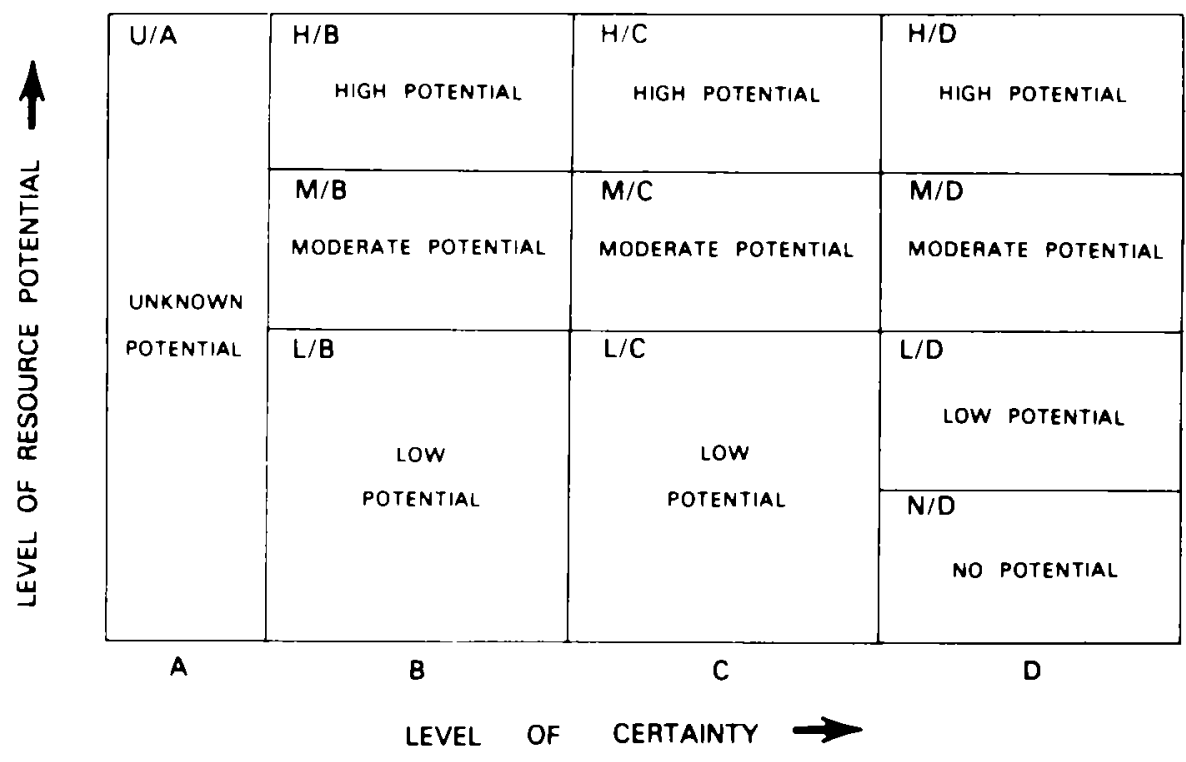

A. Available information is not adequate for determination of the level of mineral resource potential.

B. Available information suggests the level of mineral resource potential

C. Available information gives a good indication of the level of mineral resource potential.

D. Available information clearly defines the level of mineral resource potential.

Abstracted with minor modifications from:

Taylor, R. B., and Steven. T. A., 1983, Definition of mineral resource potential: Economic Geology. v. 78, no. 6, p. $1268-1270$

Taylor, R. B., Stoneman, R. J., and Marsh, S. P.. 1984. An assessment of the mineral resource potential of the San Isabel National Forest, south-central Colorado: U.S. Geological Survey Bulletin 1638. p. 40.42 .

Goudarzi, G. H. compiler. 1984. Guide to preparation of mineral survey reports on public lands: U.S Geological Survey Open-File Report $84-10787$, p. 7.8 . 


\section{RESOURCE/RESERVE CLASSIFICATION}

\begin{tabular}{|c|c|c|c|c|c|c|}
\hline & \multicolumn{3}{|c|}{ IDENTIFIED RESOURCES } & \multirow{2}{*}{\multicolumn{3}{|c|}{$\begin{array}{l}\text { UNDISCOVERED RESOURCES } \\
\text { Probability Range } \\
\end{array}$}} \\
\hline & \multicolumn{2}{|c|}{ Demonstrated } & \multirow[t]{2}{*}{ Inferred } & & & \\
\hline & Measured & Indlcated & & Hypothetical & & Speculative \\
\hline ECONOMIC & \multicolumn{2}{|c|}{$\begin{array}{c}1 \\
\text { Reserves } \\
1\end{array}$} & $\begin{array}{l}\text { Inferred } \\
\text { Reserves }\end{array}$ & \multicolumn{3}{|c|}{ 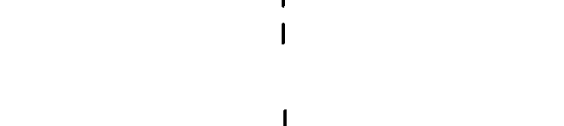 } \\
\hline $\begin{array}{l}\text { MARGINALLY } \\
\text { ECONOMIC }\end{array}$ & \multicolumn{2}{|c|}{$\begin{array}{l}\text { Marginal } \\
\text { Reserves } \\
1\end{array}$} & $\begin{array}{l}\text { Inferred } \\
\text { Marginal } \\
\text { Reserves }\end{array}$ & \multicolumn{3}{|c|}{-1} \\
\hline $\begin{array}{c}\text { SUB- } \\
\text { ECONOMIC }\end{array}$ & \multicolumn{2}{|c|}{$\begin{array}{l}\text { I } \\
\text { Demonstrated } \\
\text { Subeconomic } \\
\text { Resources }\end{array}$} & $\begin{array}{l}\text { Inferred } \\
\text { Subeconomic } \\
\text { Resources }\end{array}$ & \multicolumn{3}{|c|}{-1} \\
\hline
\end{tabular}

Major elements of mineral resource classification, excluding reserve base and inferred reserve base. Modified from U.S. Bureau of Mines and U.S. Geological Survey, 1980, Principles of a resource/reserve classification for minerals: U.S. Geological Survey Circular 831 , p. 5. 


\section{GEOLOGIC TIME CHART}

Terms and boundary ages used by the U.S. Geological Survey in this report

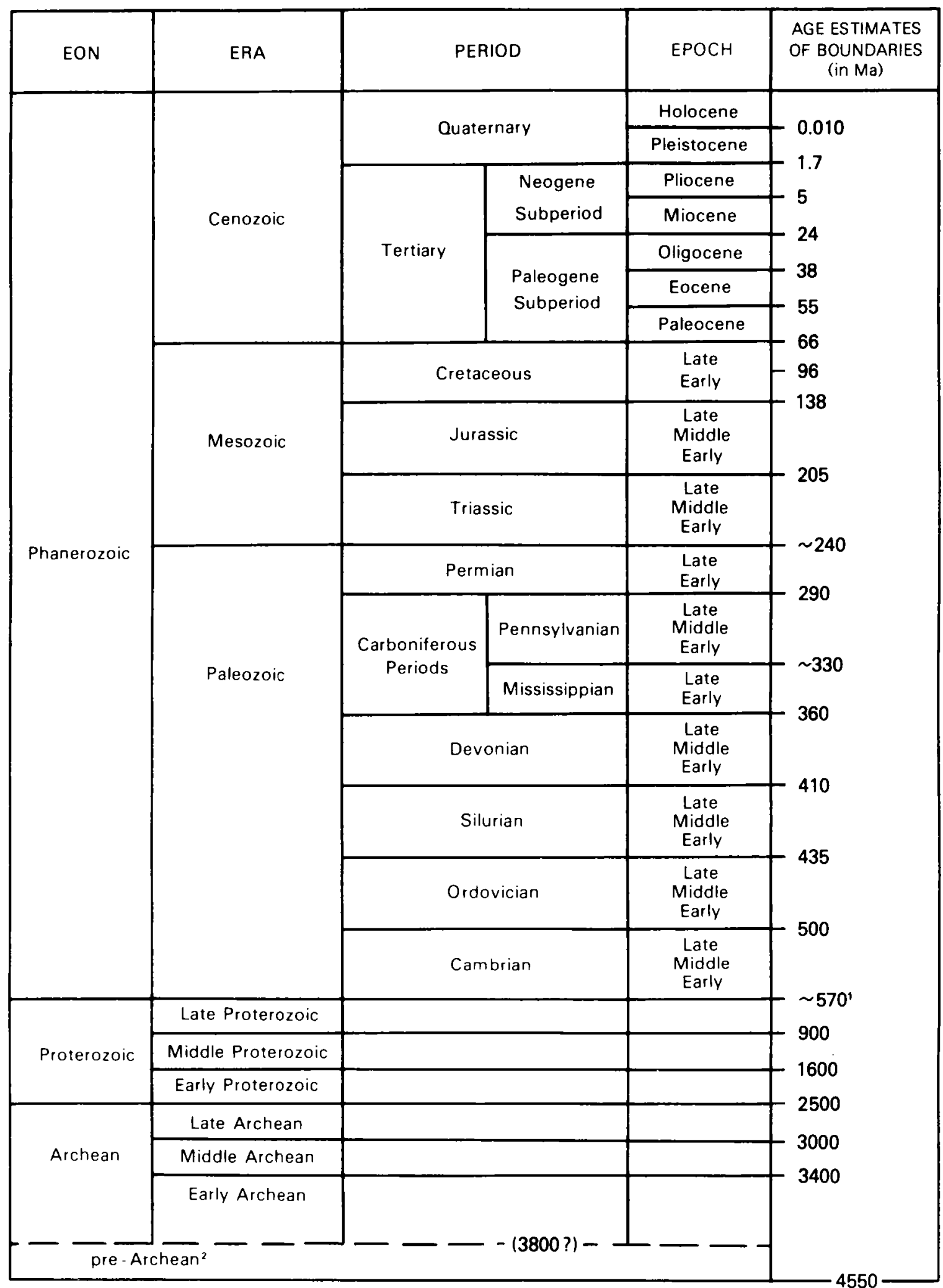

'Rocks older than $570 \mathrm{Ma}$ also called Precambrian, a time term without specific rank.

${ }^{2}$ Informal time term without specific rank. 
Table 1. Mineral deposits and occurrences in and near the Turtle Mountains Wilderness Study Area

[See figure 2 or plate 1 for locations. *, locality outside the wilderness study area boundary. Development categories: active prospect, evidence of mining activity and claim on file with U.S. Bureau of Land Management (BLM) as of August 1983; inactive prospect, evidence of mining activity but no claim on file with the BLM as of August 1983; active mine, production since 1980; inactive mine, no production since 1980.]

\begin{tabular}{|c|c|c|c|c|c|}
\hline $\begin{array}{l}\text { Map } \\
\text { number }\end{array}$ & Name & $\begin{array}{l}\text { Location } \\
\text { (unsurveyed) }\end{array}$ & Commodities & $\begin{array}{c}\text { Development } \\
\text { category }\end{array}$ & Description \\
\hline 1 & $\begin{array}{l}\text { Helen Gene No. } 1 \\
\text { claim }\end{array}$ & $\begin{array}{l}(\mathrm{SW} 1 / 4 \text { sec. } 21, \\
\text { T. } 2 \text { N., R. } 21 \text { E.) }\end{array}$ & $\mathrm{Cu}$ & $\begin{array}{l}\text { Inactive } \\
\text { prospect }\end{array}$ & $\begin{array}{l}\text { Opencut and pits; quartz vein at diabase- } \\
\text { granite contact; minor copper mineral } \\
\text { staining; copper greater than } 0.50 \\
\text { percent detected in two samples. }\end{array}$ \\
\hline 2 & Unnamed prospect & $\begin{array}{l}\text { (S. center sec. } 35, \\
\text { T. } 2 \text { N., R. } 20 \text { E.) }\end{array}$ & $\mathrm{Cu}$ & $\begin{array}{l}\text { Inactive } \\
\text { prospect }\end{array}$ & $\begin{array}{l}\text { Pits; shear zone in gneiss, malachite } \\
\text { staining; copper greater than } 0.50 \\
\text { percent detected in two samples. }\end{array}$ \\
\hline 3 & Unnamed prospect & $\begin{array}{l}(\mathrm{SW} 1 / 4 \mathrm{sec} .36 \\
\text { T. } 2 \text { N., R. } 20 \text { E.) }\end{array}$ & $\mathrm{Ag}$ & $\begin{array}{l}\text { Inactive } \\
\text { prospect }\end{array}$ & $\begin{array}{l}\text { Pit; fault zone in gneiss; calcite, } \\
\text { veinlets, hematite staining; silver } \\
\text { detected in one sample. }\end{array}$ \\
\hline 4 & Unnamed prospect & $\begin{array}{l}(\mathrm{SE} 1 / 4 \text { sec. } 36 \\
\text { T. } 2 \text { N., R. } 20 \text { E.) }\end{array}$ & $\mathrm{Ag}, \mathrm{Cu}, \mathrm{Zn}$ & $\begin{array}{l}\text { Inactive } \\
\text { prospect }\end{array}$ & $\begin{array}{l}\text { Shaft and pit; shear zone in gneiss; } \\
\text { minor malachite staining; silver } \\
\text { detected in one sample, copper and zinc } \\
\text { greater than } 1.50 \text { percent detected in } \\
\text { two samples. }\end{array}$ \\
\hline 5 & $\begin{array}{l}\text { Virginia May mine } \\
\text { and Horn spring } \\
\text { area (Horn Copper } \\
\text { mine, Mac claims) }\end{array}$ & $\begin{array}{l}(\mathrm{S} 1 / 2 \mathrm{sec} .32, \\
\text { T. } 2 \mathrm{~N} ., \mathrm{R} .21 \mathrm{E} . \\
\mathrm{NE} 1 / 4 \mathrm{sec} .6 \\
\mathrm{~N} 1 / 2 \mathrm{sec} .5 \\
\mathrm{~N} 1 / 4 \mathrm{sec} .4 \\
\text { T. } 1 \mathrm{~N} ., \mathrm{R} .21 \mathrm{E.})\end{array}$ & $\mathrm{Cu}, \mathrm{Zn}, \mathrm{Au}$, & $\begin{array}{l}\text { Inactive } \\
\text { mine, } \\
\text { active } \\
\text { prospect }\end{array}$ & $\begin{array}{l}\text { Four shafts as deep as } 70 \mathrm{ft}, 16 \text { adits as } \\
\text { long as } 620 \mathrm{ft} \text { with extensive stopes and } \\
\text { drifts, and numerous trenches and pits; } \\
\text { faulted and fractured gneiss; abundant } \\
\text { copper minerals deposited along fractures } \\
\text { and as replacement bodies, NW-trending } \\
\text { mineralized veins; gold detected in } 12 \\
\text { samples, silver detected in } 11 \text { samples, } \\
\text { copper and zinc greater than one percent } \\
\text { detected in } 51 \text { and } 25 \text { samples, respec- } \\
\text { tively; recorded production of } 1 \text {, } 178 \text { tons } \\
\text { of ore from } 1913 \text { to } 1954 \text { from Virginia May } \\
\text { mine contained } 3 \text { oz gold, } 307 \text { oz silver, } \\
\text { and } 92,280 \text { lbs copper. }\end{array}$ \\
\hline 6 & Turtle claims & $\begin{array}{l}(\mathrm{NE} 1 / 4 \mathrm{sec} .20 \\
\mathrm{SE} 1 / 4 \mathrm{sec} \cdot 21 \\
\mathrm{NE} 1 / 4 \mathrm{sec} .28 \\
\mathrm{~T} .3 \mathrm{~N} ., \mathrm{R} .20 \mathrm{E.})\end{array}$ & $\mathrm{Au}, \mathrm{Ag}$ & $\begin{array}{l}\text { Active } \\
\text { prospect }\end{array}$ & $\begin{array}{l}\text { Adit } 40 \mathrm{ft} \text { long and pit; leached, altered, } \\
\text { and sheared gneiss; abundant hematite and } \\
\text { limonite, minor quartz veinlets and } \\
\text { specularite; gold detected in three } \\
\text { samples, silver detected in two samples. }\end{array}$ \\
\hline $7 *$ & Sablon mine & $\begin{array}{l}\text { (Center sec. } 33 \\
\text { T. } 3 \text { N., R. } 20 \text { E.) }\end{array}$ & $\mathrm{Au}, \mathrm{Ag}$ & $\begin{array}{l}\text { Inactive } \\
\text { mine, } \\
\text { active } \\
\text { prospect }\end{array}$ & $\begin{array}{l}\text { Adit } 235 \mathrm{ft} \text { long, trench } 70 \mathrm{ft} \text { long, and } \\
\text { several smaller trenches and pits; shear } \\
\text { zone and quartz vein in gneiss; abundant } \\
\text { hamatite staining, minor malachite; gold } \\
\text { detected in } 19 \text { samples, silver detected } \\
\text { in } 4 \text { samples; limited past gold produc- } \\
\text { tion, total amount unknown; estimated } \\
\text { resources of } 5,400 \text { tons of ore containing } \\
0.22 \text { oz gold per ton was calculated from } \\
\text { samples from workings. }\end{array}$ \\
\hline 8 & Unnamed prospect & $\begin{array}{l}(\mathrm{SE} 1 / 4 \text { sec. } 33 \\
\text { T. } 3 \text { N., R. } 20 \text { E.) }\end{array}$ & $\mathrm{Au}, \mathrm{AB}$ & $\begin{array}{l}\text { Inactive } \\
\text { prospect }\end{array}$ & $\begin{array}{l}\text { Adit } 17 \mathrm{ft} \text { long and shaft } 30 \mathrm{ft} \text { deep; shear } \\
\text { zone and quartz vein in gneiss; abundant } \\
\text { hematite staining; gold detected in one } \\
\text { sample, silver detected in three samples. }\end{array}$ \\
\hline
\end{tabular}


Table 1. Mineral deposits and occurrences in and near the Turtle Mountains Wilderness Study Area-Continued

\begin{tabular}{|c|c|c|c|c|c|}
\hline $\begin{array}{l}\text { Map } \\
\text { number }\end{array}$ & Name & $\begin{array}{l}\text { Location } \\
\text { (unsurveyed) }\end{array}$ & Commodities & $\begin{array}{l}\text { Development } \\
\text { category }\end{array}$ & Description \\
\hline $9 *$ & $\begin{array}{l}\text { Peg-Mina and Mina- } \\
\text { Peg (Spectrum) } \\
\text { claims }\end{array}$ & $\begin{array}{l}(\mathrm{NE} 1 / 4 \text { sec. } 5, \\
\text { T. } 2 \text { N., R. } 20 \text { E.) }\end{array}$ & $\mathrm{Au}, \mathrm{Ag}, \mathrm{Pb}$ & $\begin{array}{l}\text { Inactive } \\
\text { prospect }\end{array}$ & $\begin{array}{l}\text { Adit } 25 \text { ft long with a caved shaft at portal, } \\
\text { adit } 27 \text { ft long with a caved winze, and one } \\
\text { pit; shear zone and quartz vein in } \\
\text { gneiss; abundant hematite staining; gold } \\
\text { and silver detected in one sample each, } \\
\text { lead greater than one percent detected in } \\
\text { three samples. }\end{array}$ \\
\hline $10^{*}$ & $\begin{array}{l}\text { Grand Reef } \\
\text { claims }\end{array}$ & $\begin{array}{l}(\mathrm{E} 1 / 2 \mathrm{sec} .31, \\
\text { W1/2 sec. } 32, \\
\text { T. } 3 \text { N., R. } 20 \text { E.) }\end{array}$ & $A u, A g$ & $\begin{array}{l}\text { Inactive } \\
\text { mine, } \\
\text { active } \\
\text { prospect }\end{array}$ & $\begin{array}{l}\text { Inaccessible shaft at least } 80 \mathrm{ft} \text { deep, } 13 \\
\text { adits each less than } 20 \mathrm{ft} \text { long, numerous } \\
\text { trenches and pits; hydrothermally altered } \\
\text { and faulted gneiss with quartz and } \\
\text { calcite veins; gold and (or) silver } \\
\text { detected in } 21 \text { samples each; limited gold } \\
\text { production, total amount unknown; Shannon } \\
\text { (1972) estimated reserves of } 10,000,000 \\
\text { tons of } 0.05 \text { oz gold per ton or } \\
2,000,000 \text { tons of } 0.010 \text { oz gold per ton. }\end{array}$ \\
\hline $11^{*}$ & $\begin{array}{l}\text { Black Turtle } \\
\text { (Blue Dragon) } \\
\text { claims }\end{array}$ & $\begin{array}{l}\text { (NW1/4 sec. } 6, \\
\text { T. } 2 \text { N., R. } 20 \text { E. } \\
\text { NE } 1 / 4 \text { sec. } 1, \\
\text { T. } 2 \text { N., R. } 19 \text { E.) }\end{array}$ & $\mathrm{Au}, \mathrm{Ag}, \mathrm{Cu}$ & $\begin{array}{l}\text { Inactive } \\
\text { mine, } \\
\text { active } \\
\text { prospect }\end{array}$ & $\begin{array}{l}\text { Shaft } 35 \mathrm{ft} \text { deep, two adits } 12 \text { and } 127 \mathrm{ft} \\
\text { long, a pit and an opencut; hydrothermally } \\
\text { altered and faulted gneiss and diorite } \\
\text { with specularite veins; malachite and } \\
\text { chrysocolla staining; gold detected in } \\
\text { two samples, silver detected in one } \\
\text { sample, } 0.50 \text { percent copper detected } \\
\text { in five samples. }\end{array}$ \\
\hline 12 & $\begin{array}{l}\text { Wet Mine claims } \\
\text { (Johnsons well) }\end{array}$ & $\begin{array}{l}(\mathrm{NW} 1 / 4 \mathrm{sec} .17 \\
\text { T. } 2 \text { N., R. } 20 \text { E.) }\end{array}$ & $\mathrm{Ag}$ & $\begin{array}{l}\text { Active } \\
\text { prospect }\end{array}$ & $\begin{array}{l}\text { Adit } 16 \mathrm{ft} \text { long, inclined shaft } 38 \mathrm{ft} \text { deep, } \\
\text { opencut } 37 \mathrm{ft} \text { long and numerous pits; } \\
\text { shear zones and minor quartz veins in } \\
\text { gneiss; abundant hematite staining; silver } \\
\text { detected in one sample; production unknown. }\end{array}$ \\
\hline 13 & Silica claim & $\begin{array}{l}(\mathrm{SE} 1 / 4 \text { sec. } 10 \\
\text { T. } 2 \text { N., R. } 20 \text { E.) }\end{array}$ & $\mathrm{Au}$ & $\begin{array}{l}\text { In active } \\
\text { prospect }\end{array}$ & $\begin{array}{l}\text { Inclined shaft } 25 \text { ft deep and several pits; } \\
\text { diabase dike and gneiss, minor quartz } \\
\text { veins; gold detected in two samples, } \\
\text { prospected in } 1982 \text {. }\end{array}$ \\
\hline $14=$ & Unnamed prospect & $\begin{array}{l}(\mathrm{SW} 1 / 4 \text { sec. } 8, \\
\text { T. } 1 \text { S., R. } 21 \text { E.) }\end{array}$ & $\mathrm{AB}$ & $\begin{array}{l}\text { In active } \\
\text { prospect }\end{array}$ & $\begin{array}{l}\text { Adit } 20 \mathrm{ft} \text { long; schistose zone in gneiss; } \\
\text { silver detected in one sample. }\end{array}$ \\
\hline $15^{*}$ & Angel claim & $\begin{array}{l}\text { NW1/4 sec. } 25 \text {, } \\
\text { T. } 2 \text { N.. R. } 21 \mathrm{E} .\end{array}$ & $\mathrm{Au}$ & $\begin{array}{l}\text { Active } \\
\text { prospect }\end{array}$ & $\begin{array}{l}\text { Shaft; placer occurrence in recent gravels; } \\
\text { minor gold recovered (R.E. Cross, oral } \\
\text { commun., 1981). }\end{array}$ \\
\hline 16 & $\begin{array}{l}S \text { and } W \text { claims } \\
(\text { Turtlefoot })\end{array}$ & $\begin{array}{l}\text { Center sec. } 2 \text {, } \\
\text { T. } 1 \text { S., R. } 20 \text { E. }\end{array}$ & $\begin{array}{l}\text { Onyx } \\
\text { build ing } \\
\text { stone, } \\
\text { Au, Ag }\end{array}$ & $\begin{array}{l}\text { Active } \\
\text { mine }\end{array}$ & $\begin{array}{l}\text { Pits and numerous bulldozer cuts; minor } \\
\text { gypsum and calcite-limonite staining; } \\
\text { gold and silver detected in one sample } \\
\text { each; onyx building stone produced since } \\
\text { 1977, amount unknown (Vredenburgh, 1982). }\end{array}$ \\
\hline 17 & $\begin{array}{l}\text { Craik perlite } \\
\text { deposit }\end{array}$ & $\begin{array}{l}(\mathrm{NE} 1 / 4 \mathrm{sec} .4, \\
\left.\text { T. } 3 \mathrm{~N} ., \mathrm{R}_{.} 21 \mathrm{E.}\right)\end{array}$ & Perlite & $\begin{array}{l}\text { Inactive } \\
\text { mine }\end{array}$ & $\begin{array}{l}\text { Mined for experimental material, thoroughly } \\
\text { tested; perlite occurs in flows several } \\
\text { ft thick and is associated with rhyolite, } \\
\text { tuffs, and tuffaceous sediments (Wright } \\
\text { and others, 1953). }\end{array}$ \\
\hline
\end{tabular}


Table 2. Summary of regional geochemical survey of the Turtle Mountains Wilderness Study Area

|Area shown on figure 3. $x$, distinctly concentrated; --, less distinctly concentrated. Anomaly values listed for outcrop samples are quantitative; others are semiquantitative]

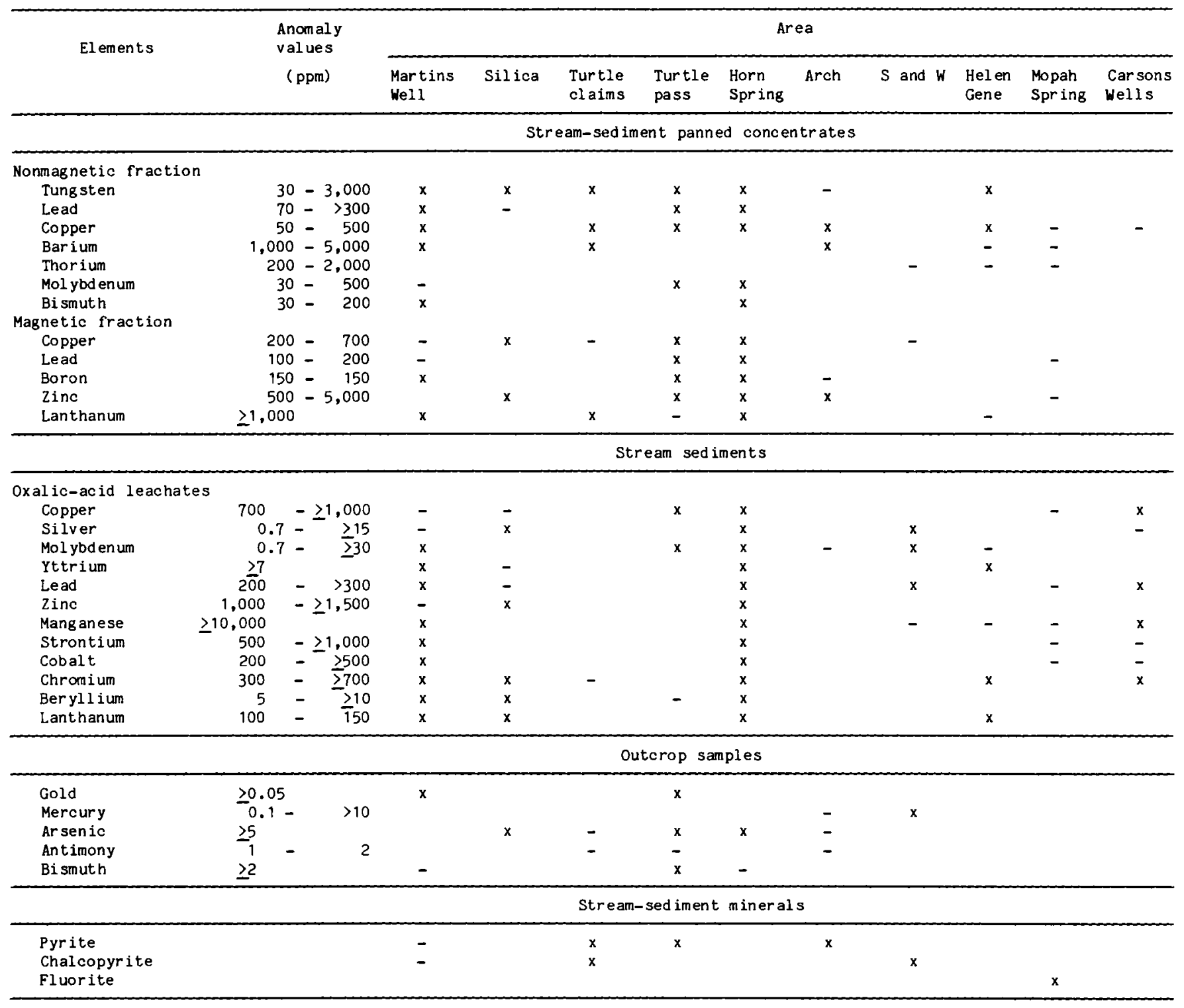



GPO 585-045/78048 


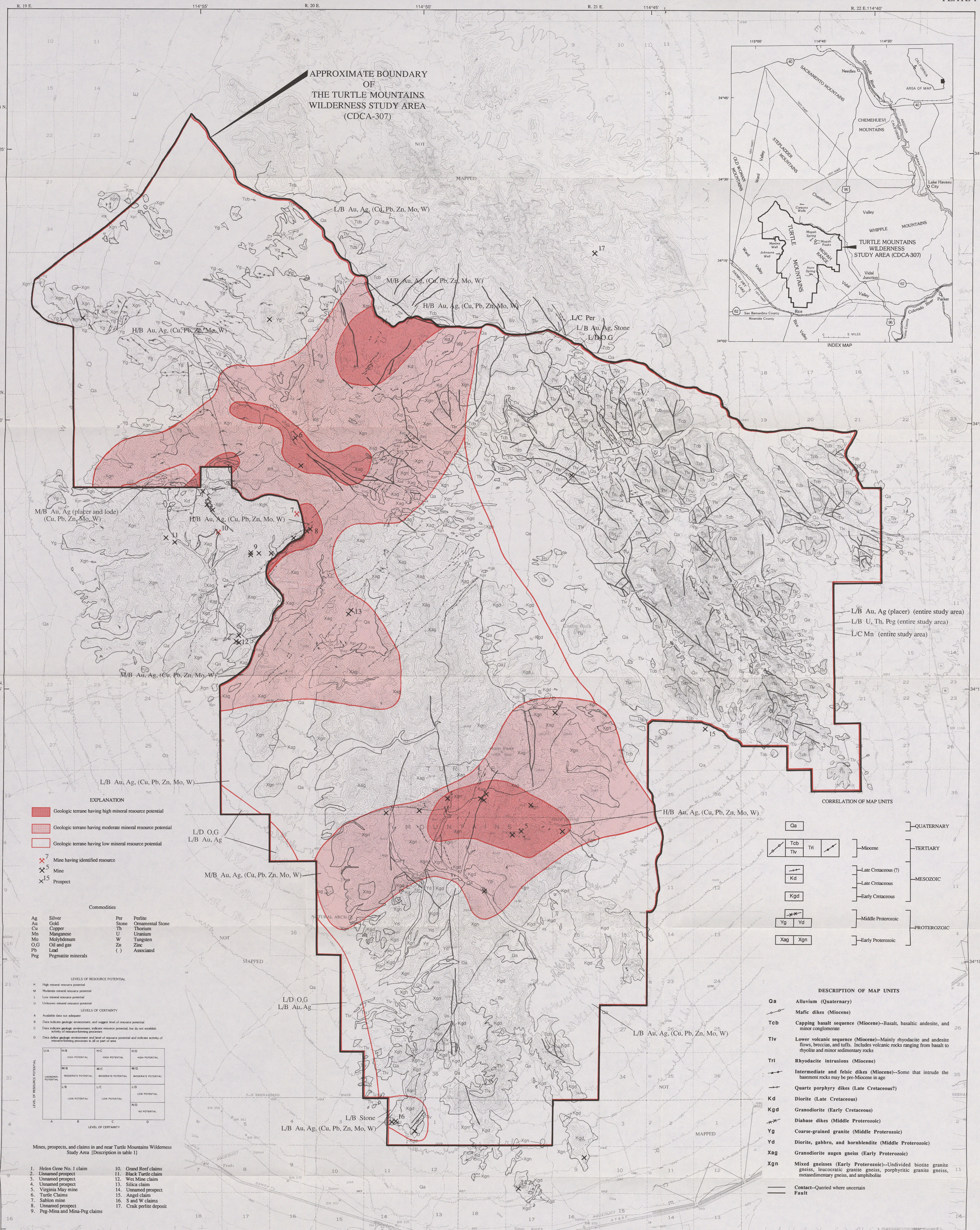


